Article

\title{
Firm's Risk-Return Association Facets and Prospect Theory Findings-An Emerging versus Developed Country Context
}

\author{
Ranjan Das Gupta *(1) and Rajesh Pathak \\ Goa Institute of Management, Goa 403505, India; rajeshp@gim.ac.in \\ * Correspondence: dasguptaranjan75@gmail.com; Tel.: +91-9830130468
}

Received: 13 November 2018; Accepted: 4 December 2018; Published: 8 December 2018

\begin{abstract}
A risk-return association under normal market conditions can be conventional positive (risk-averse) or "paradoxical" negative (risk seeking). This study has the objective to investigate whether such an association is stable across market trends (i.e., bull and bear) and for overall, industry-classified and partitions sub-samples after controlling for a firm's age, size, leverage and liquidity using operating performance risk-return measures. In total, this study analyses 2666 firms (1199 firms from 15 developed countries and 1467 firms from 12 emerging countries) for the period of 1999-2015. Results show that in the overall and bull sub-periods, firms across countries are showing conventional positive (superior firms) and "paradoxical" negative (poor firms) in most cases. However, in the bear sub-periods all firms from emerging countries are risk seeking in order to maintain their position in the pecking order.
\end{abstract}

Keywords: risk-return; Bowman's paradox; prospect theory; bull and bear; operating performance; risk measures

\section{Introduction}

Although the relation between performance and firm risk is a well-researched topic in the finance literature, empirical research has not yet provided a conclusive answer to the risk-return puzzle. Brealey et al. (2017) observe it as one of the 10 unsolved problems in finance. In an individual investor's decision-making context, the risk-return relation first comes into reality with the expected utility theory (EUT) of Von Neumann and Morgenstern (1944). It presumes risk-aversion for an individual investor, and thereby implies a positive risk-return association. However, Kahneman and Tversky (1979) in their prospect theory (PT) developments and later in their cumulative prospect theory (CPT, Tversky and Kahneman 1992) extensions question the EUT results.

Although PT explains individual's decision-making under conditions of risk and/or uncertainty, studies (see e.g., Fiegenbaum 1990; Fiegenbaum and Thomas 1988; Lee 1997; Lehner 2000; Miller and Bromiley 1991; etc. to name a few) frequently use it in explaining a firm's decision-making also. They document positive association (Fisher and Hall 1969); negative coefficients (Armour and Teece 1978; Díez-Estebana et al. 2017; Holder et al. 2016; Fiegenbaum and Thomas 1988, 2004; Miller and Chen 2003; etc.); and mixed results conditional to industry membership or firm conduct (Bettis and Hall 1982; Bowman 1980).

One of the most critical foundations of the firm's risk-return relationship is the notion that managers are generally risk averse. This approach is well accepted in formalist theories of decision making which are based on the notions of individual rationality and maximization of utility. Agency theory, a formalist theory, is also based on the assumptions of rational behavior and economic utilitarianism (Ross 1973), and thereby assumes a linear positive relationship between risk and return. 
Empirical literature associates managers' risk behavior with assumptions of rational behavior, outcome weighing and utility maximization. Financial theory also posits that risk-averse behavior manifests when low risk is associated with low return, as well as when high risk is rewarded by high return (Fisher and Hall 1969). This risk-averse outlook also assumes that for each strategic alternative, firms and managers would choose the alternative which maximizes utility (Schoemaker 1982). Aaker and Jacobson (1987) find support for a positive association between performance and both systematic and unsystematic risk, when risk is defined using accounting data. A number of other studies have also found support for a positive risk-return relationship (Bettis 1981).

To provide a theoretical lens to explain the negative association between risk and return, scholars have drawn motivation from prospect theory (Fiegenbaum and Thomas 1988; Kahneman and Tversky 1979) and behavioral theory of the firm (Bromiley 1991). Under the behavioral theory of the firm, managers undertake more risk when performance is below aspiration, and they take low risk when performance is above aspirations. Due to the contemporaneous association between risk-taking and low performance, this relationship could be negative. This is due to lower performance and higher risk in cross-sectional accounting data, or lagging effects of risk and performance would continue in the short-term in longitudinal accounting data. On the other hand, prospect theory (Kahneman and Tversky 1979) studies argue that managers in low performing firms face negatively framed prospects and are thus more likely to undertake high risk. In contrast, managers in high-performing firms face positively framed prospects and take low risk. Both of these results would cause negative correlation between high performance and low risk. Thus, prospect theory and behavioral theory of the firm provide possible explanations for the negative risk-return relationships.

The research hypotheses in these studies emphasizes on manager's and/or firm's attainment of above (below) returns in comparison to their reference (target return) levels, in turn exhibit risk-aversion (-seeking) as showed by a positive (negative) risk-return association. More specifically, we thereby follow Bowman's (1980) "risk-return paradox" and later extensions, which posit— "troubled companies take more risk" (Bowman 1982, p. 33). ${ }^{1}$ This implies-efficient decision makers (managers and/or firms) can increase return and reduce risk simultaneously. In explaining this "paradoxical" implication in light with the PT postulates, Chou et al. (2009); Fiegenbaum (1990); Fiegenbaum and Thomas (1988); Holder et al. (2016); etc. posit that agents have different risk behaviors towards gains and losses, measured with regard to a certain reference point. Many other studies analyzing corporate risk-return relation using PT-explanations empirically support Fiegenbaum and Thomas's (1988) results (see e.g., Petrou and Procopiou 2016; Bigus 2015; Chou et al. 2009; Kliger and Tsur 2011; etc.).

The specific contributions of this study are as follows. Firstly, our results extend the scant empirical literature on corporate risk-return relationships and PT-implications on an international sample of firms from 27 countries across emerging (12) and developed (15) country-settings. To the best of our knowledge, to date no study (except Díez-Estebana et al. 2017 (limited to Organization for Economic Cooperation and Development (OECD) countries only)) addresses these on such a broad scale. This issue is of major importance because national culture strongly influences firm-risk (Hofstede 2001; Li et al. 2013), and so a wider knowledge of the risk-return relation requires an international approach. A cross-country analysis can also provide interesting insights as because the country-level idiosyncrasy and national attitudes to risk does not constrain it (Bae et al. 2012; Li et al. 2013). Therefore, here we do an emerging vs. developed study, as well as take a country dummy in our multivariate regression model. Secondly, empirical literature proves (see "Leverage hypothesis" (Black 1976; Christie 1982)) that a firm's risk-return association and thereby behavioral patterns can alter across different market trends or cycles. We incorporate this by exploring firm-level accounting risk-returns association under different market cycles, i.e., by dividing the overall study period in to bull and bear sub-periods for

1 This study will be unique in its approach as it will consider both above- and below-median firms to investigate their risk-averse (conventional) and risk-seeking (paradoxical) behavior in accordance with the PT implications unlike many previous studies focusing only on "Bowman's paradox" and subsequent PT evidence. 
the international firms studied here. Horowitz et al. (2000) point out that this kind of sub-periods tests also serves as a robustness check on the resulting relationships between risk and return. Thirdly, we introduce a new measure of a firm's operating performance not used so far-the cash ratio $(C R)$, which is defined as the ratio of operating cash flow scaled by book value of assets. This is because there is strong criticism of return measures like return-on-asset $(R O A)$ and return-on-equity $(R O E)$ to be affected by the fundamental drawbacks of "accrual-based accounting" (Albrecht et al. 2004). Our CR measure represents operational efficiency and liquidity, which in turn implies quality of management (see Bettis and Mahajan 1985; Bowman 1980) and adds a firm-risk-liquidity perspective here. Fourthly, most empirical studies estimate the reference point of a firm and its risk-return association based on the time series of returns over the study periods. However, this happens only when the return distributions are constant over time. In addition, as the PT implications are extremely sensitive to a reference point, such state-dependence would provide unauthentic results. Thereby we incorporate the firm's strategic context with respect to industry-membership and firm-conduct (see Bettis and Hall 1982; Bowman 1980), by setting the target return level with respect to respective industry's performance and a firm's own performance (see Lee 1997) on a rolling basis. It allows returns distribution to change over time which is an indispensable property for accommodating PT-based explanations. This way of calculation also supports the longitudinal risk-return association ${ }^{2}$ under different market trends (bull and bear sub-periods) in this study (see negative longitudinal risk-return association reference in Bromiley 1991; Miller and Chen 2003). Fifthly, we use standard deviation of the preceding 5 years' return on a rolling basis as a proxy for risk and distance from the target outcome based on previous year's (i.e., 1-year) and preceding 5 years' (both firm's performance- and industry performance-adjusted) return as a proxy for return under all return measures. This method of calculation and subsequent analyses would neutralize earnings volatility impact in the short-term (i.e., 1 year) in line with central limit theorem (CLT). Sixthly, another major criticism of return measures like $R O A$ and $R O E$ is the problem arising out of using asset or equity value at the end of the accounting year (Baucus et al. 1993) or at the beginning (Brick et al. 2015). However, here we take the average of beginning and end of the accounting year numbers to eliminate these problems. Existing literature also states that risk-return association (especially "Bowman's paradox") is influenced by "market power" (Woo 1987), "previously existing risk-level" (Bromiley 1991; Deephouse and Wiseman 2000; Miller and Bromiley 1991), 'industry-nature and competition' (Becerra and Markarian 2013) and 'diversification' (Bettis and Hall 1982; Chang and Thomas 1989). We incorporate all these instrumental/control variables in the multivariate model and conduct partitions-study under univariate analysis. Finally, empirical evidence shows that extreme observations drive some of the famous market anomalies, such as the size effect. Knez and Ready (1997) show that after trimming only $1 \%$ of the most extreme observations, the size effect all but disappears. In addition, Horowitz et al. (2000) argue that the size effect is sample-period dependent. It is thus possible that previous empirical results supporting the "Bowman's paradox" and thereby PT findings might be affected by extreme observations. To eliminate this possibility, we trim extreme observations, i.e., risk and return measures at the $5 \%$ (bottom) and 95\% (top) levels (under one of the robustness tests).

We organize the remaining portion of this paper as follows-Next section talks about the relevant literature, Section 3 presents data and methodology, Section 4 presents the results and discussions, and Section 5 concludes the discussion, followed by references.

2 The correlation between average return measure and the standard deviation of that in the subsequent period is significant and negative. Similarly, this study uses the standard deviation of return measures for past period(s) as a proxy for risk influencing future period returns. 


\section{Literature Review and Hypotheses}

\subsection{Literature Review}

We categorize the possible explanations of the 'risk-return paradox' propagated so far into those based on PT and behavioral theory (Bromiley 1991; Cyert and March 1992; Miller and Leiblein 1996; etc.), strategic and organizational factors and model misspecifications.

The PT (Kahneman and Tversky 1979) proposes a target (i.e., reference) level of returns above which individuals (or firms) are risk-averse, but are risk-seeking below this point (see Bowman 1982, 1984; Fiegenbaum and Thomas 1988; Fiegenbaum 1990; Kliger and Tsur 2011; Lehner 2000; Díez-Estebana et al. 2017; etc.).

DasGupta (2017) in one of the most recent studies, observe that on an overall basis and also after controlling for sector, size, age for risk-return sub-samples, Indian firms show significant presence of the prospect theory implications, and below median firms exhibit presence of Bowman (1980) paradox. Díez-Estebana et al. (2017) also observe that economic contexts and the nature of major shareholders affect firms' risk-return relations. Firms controlled by families or institutional investors react more conservatively (taking or avoiding risks) to changes in corporate results. Concisely, poorly performing firms (i.e., below target levels) to take greater risks to improve their performance, which leads ex post to a negative risk-return relationship. On the other hand, the better the performance of a firm, the better it would exhibit less willingness to take additional risks in order to increase its expected returns. Thus, when a superior performing firm does assume risk, it is a risk that promises high returns. This implies a positive risk-return association for those firms. ${ }^{3}$ However, they have done it in a narrow context only for OECD countries. Holder et al. (2016) confirms paradox's existence by stating that association between risk and return is positive in "winner" firms and negative in "loser" firms. Further analysis proves that the earlier negative risk-return relationships are to be entirely due to volatility of the income statement components (i.e., short-term) of the performance terms. That is why here we take both 1-year and 5-year risk-return measures to neutralize this short-term impact. However, their study is weak due to potential endogeneity, selection biases and lack of generalizability of the results.

The second group of explanations implies that superior firms (i.e., quality management (Bettis and Mahajan 1985; Bowman 1980; Jemison 1987)) can increase returns and reduce risks simultaneously. They would use 'organizational structure and decision processes' (Jemison 1987; Wiemann and Mellewigt 1998), 'diversification pattern' (Bettis and Hall 1982; Bettis and Mahajan 1985; Wiemann and Mellewigt 1998), "market power" (Cool et al. 1989) and 'firm-size' (Perlitz and Löbler 1985; Wiemann and Mellewigt 1998) most efficiently.

Bruinshoofd and De Haan (2005) show that information and communication technology (ICT) firms tend to be smaller, less profitable and riskier. Managers of these so-called listed new-economy firms may not be as risk averse in comparison to old-economy firms. Therefore, along with capturing industry heterogeneity through industry-adjusted return measures, we also investigate the risk-return association and subsequent PT implications of old-economy manufacturing firms, and services firms including ICT firms under overall and sub-periods. ${ }^{4}$

Bettis and Hall (1982) first find the evidence that the nature of the trade-off between accounting-determined risk and return varies among related-constrained, related-linked and unrelated firms. Subsequently, Bettis and Mahajan (1985) observe that a favorable risk-return performance is extremely hard to achieve with unrelated diversification. However, for firms with 'unrelated diversification', overall risks would reduce because of low-correlation among units, but lack of synergies also drives down overall returns, and hence we expect a positive risk-return association.

3 This basic proposition helps us to formulate our two main hypotheses as presented in Data and Methodology section.

4 We do this by formulating two additional main hypotheses as presented in the Data and Methodology section. These are major and first-time contributions of this study. 
On the other hand, related diversified firms manage to reduce risks and increase returns simultaneously. Bettis and Hall (1982) and Chang and Thomas (1989) posit that for firms with a 'related diversification' strategy, correlations among different business units would be higher resulting in greater overall variability or risk with expected returns also higher, because of potential synergies among correlated business units. However, the possibility of sharing managers' skills and resources among related businesses can also lower the risk for the firm. Thereby, the relationship between risk and return would be less clear for such firms or may be "paradoxical". ${ }^{5}$

Earlier studies of Heggestad (1977) and Woo (1987) measure "market power" at the industry level by four-firm and three-firm concentration ratios. They conclude that firms with greater "market power" demonstrate greater risk-aversion ${ }^{6}$ and demand greater returns for enduring risk than firms in more competitive industries. Therefore, we here use age and firm size to control for "market power" for sample firms. This is much more reliable than concentration ratio as it implies firm-dominance across time (by their stability) and size of business (by volume). In addition, industries with fewer firms could provide skewed results in earlier studies. We eliminate this asymmetric problem here. In addition, as Dang et al. (2018) suggest we put both theoretical and empirical justification of the choice of size measure here.

Along with 'age' and 'firm-size', we also incorporate 'liquidity' and 'leverage' under both partitions sub-samples (univariate) and multivariate model as instrumental in influencing risk-return relationships for obvious empirical reasons. Acharya et al. (2007); Denis (2011); Harford et al. (2003) and Haushalter et al. (2007), all either directly or indirectly argue that cash holdings act as a hedge for firms against financing and predation risk, especially in downturns. However, we expect a negative relation between firm-size and cash holdings. So, we expect small firms to hold relatively more cash to avoid financial distress/failures (Opler et al. 1999). Conversely, firms with greater access to capital markets, i.e., large firms (with less asymmetric information problems) hold lower levels of cash (this is true for diversified firms also (see Subramaniam et al. 2011). This implies a risk-seeking attitude for larger firms and an opposite mindset by their smaller counterparts. However, pecking order theory contradicts these observations (Myers 1984). Ferreira and Vilela's (2004) free cash flow hypothesis also implies a positive relationship between cash holdings and firm's size. As pointed out by Dang et al. (2018), a firm's total assets is one of the most prominent proxies representing firm size. As total assets represent the total resources available which are invested to earn returns, it is obvious that income stream volatility and resulting income generation is directly dependent on it. All these justify our 'firm-size' partitions-study and its role as a control variable in the multivariate model.

Also, looking at the importance of cash holdings in relation to a firm's size and subsequently a firm's risk-return association, here we use average cash and cash equivalents (see Opler et al. 1999; Ramirez and Tadesse 2009) to proxy 'liquidity' under partitions-study and as a control variable in the multivariate model. This represents the liquidity impact on risk-return association for all firms, diversified and others, and in overall and sub-periods (bull and bear).

Firms also can use higher debt as a substitute for holding cash, thereby 'leverage' can act as a proxy for the ability of firms to issue debt (John 1993). This implies higher risk-taking by firms. Baskin (1987) argues that as the ratio of debt financing increases the cost of funds used to invest in liquidity increases, which would imply a reduction in cash holdings with increased debt in capital structure. Thus, in both ways it shows risk-seeking attitude of these firms. Therefore, Opler et al. (1999) and Ozkan and Ozkan (2004) predict that there should be a negative relation between a firm's cash

5 Based on the documented literature, we also formulate two additional sub-hypotheses (under the third main hypothesis for diversified firms) as presented in Data and Methodology section. These are also major and first-time contributions of this study.

6 This is in contradiction with earlier cash holdings/liquidity for large firms (see Subramaniam et al. 2011) (representing firm-size here) which this study uses as a symbol of "market power", but in line with the pecking order theory (Myers 1984) and the free cash flow hypothesis (Ferreira and Vilela 2004). 
holdings and its leverage in line with the pecking order theory (Myers 1984) and the free cash flow hypothesis (Ferreira and Vilela 2004). Therefore, here we use the debt-equity (D-E) ratio to proxy 'leverage' under partitions-study and as an instrumental/control variable in the multivariate model to incorporate its effect.

The model misspecifications issue is dealt with in Bromiley (1991), Oviatt and Bauerschmidt (1991), Henkel (2000) and Ruefli et al. (1999). Most of these issues are addressed here.

\subsection{Hypotheses}

Kahneman and Tversky (1979) PT suggests that most individuals (corporate managers as put by Fiegenbaum and Thomas (1988) and many others (see below)) are risk seeking (i.e., a "paradoxical" risk-return association) when their returns are below the reference point, and are risk-averse (i.e., a conventional positive risk-return relationship) when returns are above it. We classify a firm into the 'above' ('below') group if its average return over a sample period is higher (lower) than the reference point level (cross-sectional median here). Therefore, the most critical issue here is to identify a measure for the reference returns level.

Most empirical studies (Fiegenbaum 1990; Lehner 2000; Miller and Bromiley 1991; Brick et al. 2015; etc.) adopt the industry mean or median as the reference point. They justify this selection by citing studies of Lev (1969) and subsequent use by Frecka and Lee (1983). However, this industry benchmark as the reference point is criticized by many on the ground of variability of income across time (see Lehner 2000; and Wiseman and Bromiley 1991) and the implicit assumption of unrealized target level on which a firm's future risk-attitude depends (see Kliger and Tsur 2011). Lee (1997) and others emphasize using a firm's own past performance as the reference point in this regard.

Therefore, in line with our study objectives to examine the nature of association between risk and return, it uses both sample firm's own average past performance (for 1 year (short-term) and preceding 5 years (long-term) on a rolling basis (i.e., a firm's time series mean)) and cross-sectional industry mean for similar period(s) on a rolling basis. We do this to calculate its reference return level (i.e., the cross-sectional median values of the overall group and all sub-groups (partitions and periods)) (detailed discussion in next sub-section) for dividing firms in above- and below-median sub-samples.

In line with the Bowman's (1980) 'paradox' (for below-median firms) and conventional positive (for above-median firms) risk-return association, and therefore PT perspectives, and also after reviewing the results of the previous empirical studies, this study mainly investigates the following two research hypotheses:

Hypothesis 1 (H1). A negative association between risk and return exists for firms below reference return levels (i.e., cross-sectional median returns).

Hypothesis 2 (H2). A positive association between risk and return exists for firms above reference return levels (i.e., cross-sectional median returns).

The above two main hypotheses imply risk-seeking and risk-averse attitudes respectively of the decision-maker in line with PT implications.

Additionally, for the first time, we examine the following main and sub-hypotheses here to find the respective firm- or industry-classified risk-return association and PT implications on a case-by-case basis:

Hypothesis 3 (H3). Normal positive (negative) risk-return association exists for diversified firms.

Hypothesis 3.1 (H3.1). Unrelated diversified firms always show positive risk-return association.

Hypothesis 3.2 (H3.2). Related diversified firms always show negative (or unclear) risk-return association. 
Hypothesis 4 (H4). Service (new economy) firms always show negative risk-return association.

Hypothesis 5 (H5). Manufacturing (old-economy) firms always show positive risk-return association.

We investigate all these hypotheses here in the presence of control/instrumental variables of size, age, leverage and liquidity under both univariate (partitions-study) and multivariate models that would imply respective PT findings.

\section{Data and Methodology}

\subsection{Data}

This study uses BLOOMBERG for obtaining annual (as on 31 December each study year in \$ terms) financial data of sample firms. Initially it starts with the sample of all firms listed in the benchmark indices of 29 countries (15 developed and 14 emerging (see Table 1)) worldwide. However, we exclude firms in Sri Lanka and Vietnam due to inadequate numbers. Finally, it includes only those firms, which have been existing continuously in between 1999-2015 and for which data are available. This translates into a final full sample of 45,322 firm-years (i.e., 2666 firms continuously existing for 17 years).

For each sample firm, this study estimates the $R O A, C R$ and $R O E$ (under robustness tests) accounting return measures (see Table 2). Here, $R O A$ and $R O E$ are calculated by dividing net income at time $t$ by average of time $t-1$ (i.e., as on 1 January each study year) and time $t^{\prime}$ s total assets and shareholders' equity on a rolling basis. We calculate $C R$ by dividing operating cash flow at time $t$ by average of time $t-1$ and time $t^{\prime}$ s total assets. So, $R O A_{f, t}, R O E_{f, t}$ and $C R_{f, t}$ are respective accounting returns of firm $f$ at year $t$.

Table 1. Demographic data. This table provides number of companies of each country studied under this work. In total, we study 2666 firms (1199 firms from 15 developed countries and 1467 firms from 12 emerging countries) here.

\begin{tabular}{cc}
\hline Countries (Developed) & Number of Firms \\
\hline AUSTRALIA & 130 \\
BELGIUM & 13 \\
CANADA & 154 \\
FRANCE & 37 \\
GERMANY & 29 \\
HONG KONG & 35 \\
JAPAN & 169 \\
KOREA & 90 \\
NEWZELAND & 22 \\
SINGAPORE & 22 \\
SPAIN & 19 \\
SWITZERLAND & 17 \\
UK & 71 \\
USA & 371 \\
NETHARLANDS & 20 \\
AREGENTINA & 19 \\
BRAZIL & 31 \\
MEXICO & 23 \\
CHINA & 718 \\
INDIA & 261 \\
INDONESIA & 215 \\
MALAYASIA & 21 \\
PAKISTAN & 66 \\
PHILIPPINES & 23 \\
TAIWAN & 34 \\
THAILAND & 27 \\
CHILI & 29 \\
SRI LANKA & 03 \\
VIETNAM & 01 \\
\hline
\end{tabular}


Table 2. Description of variables. This table depicts the variables (dependent, independent, control and dummy) undertaken in this study. Here, return on asset $(R O A)$, cash ration $(C R)$ and return on equity $(R O E)$ are the main independent variables and standrad deviations $(S D)$ of them are the dependent variables in the regression model. In addition, firm's target returns (FTR) and industry-adjusted target returns (ITR) for the short-term (1 year) and long term (5 years) are influencing firm-risk. We take size, age, leverage and liquidity as control variables and related diversified, unrelated diversified, financial firms and country as dummy variables.

\begin{tabular}{|c|c|}
\hline ROA (Return on Assets) & Net income/Book value of assets (average) [(beginning + ending)/2] \\
\hline CR (Cash Ratio) & Operating cash flow / Book value of assets (average) [(beginning + ending)/2] \\
\hline ROE (Return on Equity) & Net income/Book value of shareholders' equity (average) [(beginning + ending)/2] \\
\hline$F T R_{t}$ & $\begin{array}{l}\text { Firm's target return level in the } t \text { th year }\left(F T R_{1} \text { year }\right) \text { or for preceding } t \text { years }\left(F T R_{5} \text { years }\right) \\
F T R_{1} \text { year }=\text { Actual Return }_{f, t-1} ; F T R_{5} \text { years }=\text { Mean-return } n_{f, t-1 \ldots t-5}\end{array}$ \\
\hline$I T R_{t}$ & See Appendix A \\
\hline Standard deviation $(\sigma)$ & $\begin{array}{l}\text { Represents risk and calculated as: } \\
\sigma(A R)_{t}=\sqrt{\sum_{j=t-5}^{t-1} \frac{\left(A R_{j}-\overline{A R}\right)^{2}}{n-1}} \\
\text { where, } t=2004,2005, \ldots, 2015 \\
A R=R O A, R O E \text { and } C R\end{array}$ \\
\hline Size & Average total assets [(beginning + ending) $/ 2]$ in year $t$ \\
\hline Age & Present year-Year of incorporation \\
\hline Leverage & Average [(beginning + ending)/2] of (Total debt/Total assets) in year $t$ \\
\hline Liquidity & Average [(beginning + ending)/2] of cash \& cash equivalents in year $t$ \\
\hline Related Diversification & Diversified firms in the same or related industry, 1 if so otherwise 0 \\
\hline Unrelated Diversification & Diversified firms in different industries, 1 if so otherwise 0 \\
\hline Financial & $\begin{array}{l}\text { Firms from banking, Non-banking financial companies (NBFCs) and other } \\
\text { finance-related industries (brokerages, etc.) regulated by authorities, } 1 \text { if so otherwise } 0\end{array}$ \\
\hline Country & Emerging (0) and developed (1) \\
\hline
\end{tabular}

\subsection{Risk and Return Measurement}

Earlier empirical studies (see Lehner 2000; etc.) investigating Bowman's 'paradox' in risk-return association internationally emphasize Fishburn's (1977) measure of risk. Fishburn (1977) re-models the risk-concept by suggesting that risk is not necessarily a measure of deviation about an expected value but a function of distance from a target outcome.

Therefore, this study uses the idea of target return level in developing the model. In this study, we calculate the target return (henceforth TR) level for a firm for each year in two ways (in line with DasGupta 2017):

In the first case, the target return level for firm $f$ (henceforth $F T R$ ) in year $t$, i.e., $F T R_{f, t}$, is calculated as the firm's return in the preceding year (henceforth $F T R_{1}$ year (to investigate short-term impact)), and also firm's mean return for preceding 5 years (henceforth $F T R_{5}$ years (to investigate long-term impact)) on a rolling basis (see Table 2).

To make this study more robust, another industry-adjusted target return level (henceforth ITR) is also used. This enables each firm to control the exogenous factors' impact on its own whole industry, uncontrollable by such firms individually. We further assume here that all such factors affect all firms in a specific industry in a similar way.

Risk (henceforth $\sigma$ ) is measured as ex post standard deviation of individual firm's actual returns (henceforth $A R$ ) for preceding 5 years on a rolling basis (see Table 2). This allows distribution of returns change over time, a property that is indispensable for accommodating PT-based actions. 


\subsection{Time, Industry-Classification, and Size, Age, Leverage and Liquidity Partitions' Effects}

While investigating the risk-return association and probable PT implications for sample firms, this study for the first time incorporates a sub-periods study in the form of bull and bear sub-periods. We classify the bull and bear sub-periods by comparing country-wise annualized monthly benchmark indices returns with the Morgan Stanley Capital International Inc.'s (MSCI) world index's similar returns for each study year. Accordingly, in all years, some countries are exhibiting bull market cycles and some others are in bear sub-periods.

This study also divides all the 2666 firms representing 101 industry-groups in manufacturing (total firms is 1645) and service (total firms is 1021) based on the old vs. new economy idea (see Bruinshoofd and De Haan 2005). Regarding the partitions analysis as undertaken in this study, this kind of additional industry-classified investigation is necessary. This is because they differ in terms of size, age, leverage and liquidity. In addition, we investigate 101 diversified firms (related and unrelated) and 278 financial firms (additionally) separately to examine the sub-hypotheses undertaken in this study. This study also conducts all analyses only on 2388 non-financial firms under one of the robustness tests to make it more robust.

As previously discussed in the Literature Review section, size, age, leverage and liquidity also influence the risk-return association of individual firms and thereby PT implications.

This study measures 'firm-size' by their reported book value of assets as on 31 December of the year of analysis (in line with DasGupta 2017). It sorts the sample firms in ascending order of their asset size and then divides the sample into bottom and top 50\%. It considers the bottom group of firms as small firms and the top group as large firms and repeat the entire analysis for each of these sub-samples. If "market power" is a potential cause for Bowman's paradox (i.e., negative risk-return association for below-median firms), and if larger firms do have higher market power, which is a logical expectation, then such firms would not exhibit any 'paradox' (see Heggestad 1977; and Woo 1987). Although this is theoretically proved under pecking order theory (Myers 1984) and Ferreira and Vilela's (2004) free cash flow hypothesis; however, this contradicts with the earlier mentioned liquidity perspective, i.e., large firms hold less cash and are thereby vulnerable to risk (see Opler et al. 1999; and Subramaniam et al. 2011).

This study measures firm's 'age' by the number of elapsed years since inception at the point of analysis (in line with DasGupta 2017). It calculates the age of the firms every year as the difference from that year to the year of inception. It then sorts the firms based on their age again in an ascending order based on their age, and divides the sample as in the case of size-partitions into young and old firms. It also repeats the entire analysis for the old and young firms. If "market power" would have an impact on Bowman's 'paradox', and as it is logical to assume older firms which survived for some length of time have higher market power, then the older firms would not exhibit evidence of Bowman's 'paradox'.

This study also uses the reported debt-equity-ratio (i.e., D-E ratio) (proxy of 'leverage' (i.e., for 'previously existing risk')), average cash and cash equivalents (proxy of 'liquidity' of the firms each year, follows an exactly similar strategy as above, and divides its sample into low and high leverage and liquidity firms. As mentioned above, a firm with higher leverage or lower liquidity is expected to have the tendency to exhibit Bowman's 'paradox', while low leverage or high liquidity firms will not exhibit the same.

\subsection{Test Design}

We want to investigate "Bowman's paradox" for below-median firms and conventional positive risk-return association for above-median firms after considering Fishburn's (1977) measure of risk. Therefore, we split the overall sample and all partitioned sub-samples and sub-periods sub-samples (both for FTR and ITR, 1 year and 5 years cases) in two divisions for each return variable-above and below. This respectively corresponds firms above and below of the cross-sectional median value (i.e., reference point level) of the whole group for the variable in each case. 
The PT and Fishburn's measure of risk suggest that decision makers are more willing to accept variability the further below target they find themselves. So, the standard deviation $(\sigma)$ of outcome (i.e., returns) is related to distance from target (DT) when decision makers are above- or below-median levels. This study defines DT (for FTR (1 year and 5 years)) as follows:

$$
\begin{aligned}
& D T R O A_{f, t}=A R R O A_{f, t}-A R R O A_{f, t-1}(1 \text { year }) \\
& D T R O A_{f, t}=A R R O A_{f, t}-\text { MeanROA }_{f, t-1 \ldots t-5} \text { (5 years) } \\
& D T C R_{f, t}=A R C R_{f, t}-A R C R_{f, t-1} \text { (1 year) } \\
& D T C R_{f, t}=A R C R_{f, t}-\text { MeanCR } R_{f, t-1 \ldots t-5} \text { (5 years) }
\end{aligned}
$$

where

$D T R O A_{f, t}$ and $D T C R_{f, t}=$ Distance from the target return level of the individual firm (i.e., $F T R_{f, t}$ ) in year $t$.

$A R R O A_{f, t}$ and $A R C R_{f, t}=$ Actual return of $R O A$ and $C R$ respectively, for firm $f$ in year $t$.

$A R R O A_{f, t-1}$ and $A R C R_{f, t-1}=$ Actual return of $R O A$ and $C R$ respectively, for firm $f$ in year $t-1$ (i.e., preceding year).

MeanROA $A_{f, t-1 \ldots t-5}$ and MeanCR $_{f, t-1 \ldots t-5}=$ Mean return of $R O A$ and $C R$ respectively, for firm $f$ in year $t-1 \ldots t-5$ (i.e., preceding 5 years) on a rolling basis.

Similarly, DT for ROE and DT (for ITR (1 year and 5 years)) are also calculated (see Appendix B).

Then all these time series mean of distances from the target return levels (return measure) and the standard deviations (see Equation (1)) acting as the measure of risk are analyzed by Kendall's correlation results for all accounting return variables as taken here. We also conduct scatter plot tests ${ }^{7}$ to justify the model as used, but the results are not shown here for the sake of brevity.

Here, as the data is non-normal or ordinal and as there are outliers, we use Kendall's (1938) test over and above other (including Pearson's) correlation tests. We use Kendall's test to measure the correlations between these accounting variables' risk and return measures within the relevant groups (overall, sub-periods and all sub-samples). Kendall's possible values range from +1 (perfect positive correlation) to -1 (perfect negative correlation), with the absolute value of $\tau$ indicating the strength of the monotonic relationship between the two variable (Chen and Popovich 2002; Liebetrau 1976). However, if Kendall's value is consistently negative below the median level and positive above the reference point level, such results would tend to support the "Bowman's paradox" (for below-median firms) and conventional positive risk-return association (for above-median firms), and thereby the PT implications for all such firms.

\subsection{Multivariate Regression Model}

Along with the univariate analysis through Kendall's correlation results, this study carries out a multivariate regression model (see DasGupta 2017) as shown below ${ }^{8}$ :

$$
\begin{gathered}
\sigma_{f, t}=\alpha+\beta_{1} \text { RETURN }_{f, t}+\beta_{2} \text { DTSTFTR }_{f, t}+\beta_{3} \operatorname{DTLTFTR}_{f, t}+\beta_{4} \operatorname{DTSTITR}_{f, i, t}+ \\
\beta_{5} \operatorname{DTLTITR}_{f, i, t}+\beta_{6} \operatorname{SIZE}_{f, t}+\beta_{7} \operatorname{AGE}_{f, t}+\beta_{8} \operatorname{LEVERAGE}_{f, t}+\beta_{9} \operatorname{LIQUIDITY}_{f, t}+ \\
\beta_{10} \text { RELATEDDIVERSIFICATION }_{f, t}+\beta_{11} \operatorname{UNRELATEDDIVERSIFICATION~}_{f, t}+ \\
\beta_{12} \text { FINANCIALFIRM }_{f, t}+\beta_{13} \operatorname{COUNTRY}_{f, t}+\varepsilon_{f, t}
\end{gathered}
$$

where:

$\sigma_{f, t}=$ Risk measured by the standard deviation of the performance (return) measures for firm $f$ at time $t$.

7 These results have pointed out the linear nature of datasets with minimum number of outliers. This motivates this study to apply Kendall's (1938) correlation test initially and multivariate regression model for further analysis. In addition, we conduct outlier-trimming robustness check tests here for making these results more authentic.

8 In the first robustness test of all firms excluding financial firms, the financial firm dummy is not incorporated. Similarly, in the investigation of related and unrelated diversified firms' cases, the respective dummy variable is also not incorporated. 
$R E T U R N_{f, t}=$ Performance of the firm measured by $R O A, R O E$ or $C R$ in year $t$.

$D_{T S T F T R} f_{f, t}=$ Distance from the short-term (i.e., 1 year) target return level for the individual firm $(f)$ in year $t$ for $R O A, R O E$ or $C R$.

$D_{T L T F T R}, t=$ Distance from the long-term (i.e., 5 years) target return level for the individual firm $(f)$ in year $t$ for $R O A, R O E$ or $C R$.

$\operatorname{DTSTITR}_{f, i, t}=$ Distance from the short-term (i.e., 1 year) target return level (i.e., cross-sectional industry mean return for preceding year) for the individual firm $(f)$ in industry $i$ in year $t$ for $R O A, R O E$ or $C R$.

$\operatorname{DTLTITR}_{f, i, t}=$ Distance from the long-term (i.e., 5 years) target return level (i.e., cross-sectional industry mean return for preceding 5 years on a rolling basis) for the individual firm $(f)$ in industry $i$ in year $t$ for $R O A, R O E$ or $C R$.

$\alpha=$ Constant; $\beta_{1}, \beta_{2}, \ldots, \beta_{13}=$ Coefficients; and $\varepsilon_{f, t}=$ Error term.

In addition, in the model, size, age, leverage and liquidity are control variables and dummy variables for related and unrelated diversified firms, financial firms and country (emerging or developed) ( 0 or 1 ) are included.

Among these variables, actual return (ROA, ROE or $C R)$ of firm $f$ in time $t$ is the main independent variable of interest. Also, DTSTFTR $R_{f, t}$ and $\operatorname{DTLTFTR}_{f, t}$ (when this study is using a firm's own past short- and long-term actual or mean return as the TR) and DTSTITR $R_{f, i, t}$ and DTLTITR $R_{f, i, t}$ (when this study is using cross-sectional industry short- and long-term mean return as the TR) would further strengthen its multivariate findings. If the slope coefficient, i.e., $\beta_{1}, \beta_{2}, \beta_{3}, \beta_{4}$, or $\beta_{5}$, in individual cases, ends up being positive and significant, it should convey a conventional positive risk-return association for above-median firms mainly, whereas in case of below-median firms, negative and significant coefficient results would imply evidence of a Bowman's (1980) "paradox". ${ }^{9}$

To test the robustness of study results further, this study conducts four additional robustness check tests. Firstly, it incorporates another operating performance measure i.e., $R O E$ to find whether study results are contingent on return measures undertaken in the main study or uniform across variables. Secondly, it excludes 278 financial firms from the initial sample of 2666 firms across countries and conducts all the above tests. This is because financial firms notably have a highly regulated business, as they must comply with strict legal requirements pertaining to their financing decisions, whereas managers of non-financial counterparts have considerable leeway in this regard. Thirdly, we undertake an additional robustness check test by trimming firms whose return measures (and thereby standard deviation of $R O A$ and $C R$ ) fall outside the range of $6-95 \%$ of the datasets. This implies that this study trims bottom 5\% and top 5\% in second robustness check test's computations. Here also, we conduct all the above tests for the overall trimmed sample, sub-periods and partitions wise sub-samples respectively (See Chou et al. (2009) for detailed discussion). Finally, we run both fixed and random effects model of regressions with same explanatory variables and controls for both $R O A$ and Cash ratio based risk measures to substantiate further our original findings.

Gaud et al. (2005) discuss the limitations of estimating a static model by using a fixed or random effect panel. On the other hand, Arellano and Bover (1995) and Blundell and Bond (1998) suggest that first difference Generalized Method of Moments (GMM) estimator also has limitations. These deficiencies can be overcome by the GMM system estimator (see Wafa and Hédi 2018). For this reason, Arellano and Bover (1995) and Blundell and Bond (1998) propose system GMM estimator to solve problems than with difference GMM. In addition, in case of unbalanced panel data, as here, Roodman (2009) indicates that it is better to use system GMM and avoid difference GMM estimation. Greene (2008) also observes that system GMM has the advantages of robustness to endogeneity and the short panel bias (see Buvanendra et al. 2017). So, to make our study more robust we run a system GMM estimation and show the comparative results under robustness tests results.

9 This study is trying to figure out the risk level assumed by the firm to generate that return under a certain given reported return performance. Hence, it uses risk as the dependent and target returns as the independent variables in the model. 


\section{Results and Discussions}

\subsection{Descriptive Statistical Results}

Results (see Appendix A) show that emerging countries firms are taking higher risks (SD) to earn higher return $(R O A / R O E / C R)$, but fail in the process to imply a negative risk-return association across overall and bull and bear sub-periods. In bear periods, below-median firms from developed countries are also showing similar trends. Above-median (superior) firms show mixed results, only sometimes positive risk-return association across return measures and time-periods. Manufacturing firms, both superior and poor, from emerging countries are also displaying a "paradoxical" (i.e., negative (high-risk-low-return)) risk-return association across time-periods. This is similar to poor service firms from emerging countries. However, superior service firms are taking lower risks to earn above-normal returns, thereby also showing a negative risk-return association. Results also show that manufacturing firms are contributing most to the overall performance, but service firms are more risky. Diversified firms have lower risk with lower returns. These results hold true in the overall period, and in bull and bear sub-periods.

Results also show that large firms, old firms, low leverage firms and high liquidity firms are earning relatively higher returns, but by taking lower risks. So, they are showing a "paradoxical" (i.e., low-risk-high-return) association between a firm's risk and return. Small firms, young firms, high leverage firms (obvious reasons) and low liquidity firms are, however, taking higher risk, but earning modest to lower returns (i.e., high-risk-low-return). Therefore, it is evident that firms' partitions clearly document a risk-seeking attitude for all sample firms. All these results are identical in cases of emerging countries firms. However, in cases of developed countries firms in all partitions, we have a conventional positive risk-return association, i.e., small firms, young firms, low leverage firms and low-liquidity firms all are risk-seeking to earn relatively higher returns than their partition counterparts.

So, overall, a conventional positive risk-return relationship for above-median firms (only in some cases) and Bowman's "paradoxical" risk-return association for their below-median counterparts in all cases are providing ample support to carry our investigation further here by using univariate (Kendall's correlation) and multivariate regression model followed by PT implications. Especially emerging countries firms document interesting findings, which are in line with overall results, whereas developed countries firms are showing deviations from the theoretical arguments.

\subsection{Kendall's Correlation Results}

This section presents the Kendall's correlation results for the overall sample and all sub-samples undertaken here.

\subsubsection{Kendall's Correlation Results-Overall Period}

Tables 3, 5 and 5 are showing Kendall's correlation results for overall sample, industry-classified and partitions sub-samples for the overall study period. They also depict respective results for developed and emerging countries firms. Overall and developed countries' above-median firms present a conventional positive risk-return association. However, emerging countries firms show mixed results (both risk-seeking and -averse) under different return measures. Therefore, this implies that they are contingent to returns. It is also clearly evident from Table 3 that below-median firms (overall and emerging countries) are significantly showing negative (i.e., "paradoxical") risk-return relationship under all return measures both in short- and long-term's firm- and industry-adjusted target returns (i.e., FTR and ITR for 1 year and 5 years). However, poor performers from developed countries are also mostly risk averse as is documented with a significant conventional positive risk-return association. Therefore, we validate Hypotheses 1 and 2 only partially. 
Table 3. Kendall's correlation results. This table provides Kendall's $\tau$ correlation results for the overall sample of 2666 firms (1199 firms from 15 developed countries and 1467 firms from 12 emerging countries) after dividing them in above- and below-median firms based on cross-sectional median values. Here, $R O A$ stands for return on assets, $R O E$ represents return on equity and $C R$ denotes cash ratio. FTR stands for firm-adjusted target return and ITR implies industry-adjusted target return. We calculate for 1-year and 5-year time periods on a rolling basis.

\begin{tabular}{|c|c|c|c|c|c|c|c|c|c|c|c|c|}
\hline & \multicolumn{4}{|c|}{ Overall } & \multicolumn{4}{|c|}{ Developed } & \multicolumn{4}{|c|}{ Emerging } \\
\hline \multicolumn{13}{|c|}{ Above-median firms } \\
\hline Variables & $F T R_{1}$ year & $F T R_{5}$ years & $I T R_{1}$ year & $I T R_{5 \text { years }}$ & $F T R_{1}$ year & $F T R_{5}$ years & $I T R_{1 \text { year }}$ & $I T R_{5 \text { years }}$ & $F T R_{1}$ year & $F T R_{5}$ years & $I T R_{1}$ year & $I T R_{5}$ years \\
\hline$R O A$ & 0.007 & $0.078^{* * *}$ & -0.001 & $0.052^{* * *}$ & -0.016 & $0.062^{* *}$ & $0.105^{* * *}$ & $0.153^{* * *}$ & 0.005 & $0.081^{* * *}$ & $0.068^{* * *}$ & $0.125^{* * *}$ \\
\hline$R O E$ & $-0.097^{* * *}$ & $0.074^{* * *}$ & $-0.046^{* *}$ & 0.015 & $-0.080^{* * *}$ & $0.093^{* * *}$ & $-0.072^{* * *}$ & 0.004 & $-0.120^{* * *}$ & $0.044^{*}$ & $-0.046^{*}$ & 0.005 \\
\hline$C R$ & -0.012 & 0.029 & -0.004 & 0.015 & 0.005 & 0.023 & -0.032 & -0.038 & -0.013 & 0.024 & -0.026 & -0.018 \\
\hline \multicolumn{13}{|c|}{ Below-median firms } \\
\hline$R O A$ & $-0.053^{* * *}$ & $-0.044^{* *}$ & $0.185^{* * *}$ & $0.182^{* * *}$ & 0.013 & $0.045^{*}$ & $0.167^{* * *}$ & $0.184^{* * *}$ & $-0.049^{* *}$ & $-0.058^{* *}$ & $0.176^{* * *}$ & $0.169^{* * *}$ \\
\hline$R O E$ & 0.025 & 0.028 & $-0.074^{* * *}$ & -0.026 & 0.021 & $0.108^{* * *}$ & $-0.081^{* * *}$ & -0.008 & 0.040 & -0.023 & $-0.048^{*}$ & -0.032 \\
\hline$C R$ & -0.020 & $-0.084^{* * *}$ & $0.036^{* *}$ & 0.017 & -0.003 & -0.039 & $-0.054^{* *}$ & $-0.059^{* *}$ & 0.016 & $-0.050 * *$ & $-0.055^{* *}$ & $-0.056^{* *}$ \\
\hline
\end{tabular}

${ }^{* * *}$ Correlation is significant at the 0.01 level (2-tailed). ${ }^{* *}$ Correlation is significant at the 0.05 level (2-tailed). ${ }^{*}$ Correlation is significant at the 0.10 level (2-tailed). 
Table 4. Kendall's correlation results. This table provides Kendall's $\tau$ correlation results for 1645 manufacturing (old-economy) (722 firms from 15 developed countries and 923 firms from 12 emerging countries) and 1021 service (new-economy) (477 firms from 15 developed countries and 544 firms from 12 emerging countries) firms after dividing them in above- and below-median firms based on cross-sectional median values. This also includes similar results for 101 diversified (56 related and 45 unrelated) firms across 27 countries. We calculate for 1-year and 5-year time periods on a rolling basis.

\begin{tabular}{|c|c|c|c|c|c|c|c|c|c|c|c|c|}
\hline & \multicolumn{4}{|c|}{ Overall } & \multicolumn{4}{|c|}{ Developed } & \multicolumn{4}{|c|}{ Emerging } \\
\hline \multicolumn{13}{|c|}{ A. Manufacturing } \\
\hline \multicolumn{13}{|c|}{ Above-median firms } \\
\hline Variables & $F T R_{1}$ year & $F T R_{5}$ years & $I T R_{1}$ year & $I T R_{5}$ years & $F T R_{1}$ year & $F T R_{5}$ years & $I T R_{1}$ year & $I T R_{5}$ years & $F T R_{1}$ year & $F_{T R}$ years & $I T R_{1}$ year & $I T R_{5}$ years \\
\hline$R O A$ & -0.031 & 0.040 * & -0.027 & 0.030 & -0.028 & 0.032 & $0.094^{* * *}$ & $0.150^{* * *}$ & -0.011 & $0.074^{* *}$ & $0.089^{* * *}$ & $0.157^{* * *}$ \\
\hline$R O E$ & $-0.141^{* * *}$ & $0.052^{* *}$ & $-0.050^{* *}$ & 0.016 & $-0.110^{* * *}$ & $0.073^{* *}$ & $-0.105^{* * *}$ & -0.021 & $-0.157^{* * *}$ & $0.052 *$ & -0.014 & 0.031 \\
\hline$C R$ & 0.006 & $0.059 * *$ & 0.019 & $0.051 * *$ & 0.025 & $0.069 *$ & -0.025 & -0.028 & -0.043 & -0.002 & 0.000 & 0.007 \\
\hline \multicolumn{13}{|c|}{ Below-median firms } \\
\hline$R O A$ & -0.010 & 0.006 & $-0.063^{* * *}$ & -0.015 & 0.028 & 0.024 & $0.081 * *$ & $0.096^{* * *}$ & 0.018 & 0.043 & 0.027 & 0.028 \\
\hline$R O E$ & $0.041 *$ & 0.025 & $-0.103^{* * *}$ & -0.041 & 0.015 & $0.074^{* *}$ & $-0.077^{* *}$ & -0.001 & $0.060 * *$ & -0.006 & -0.038 & -0.015 \\
\hline$C R$ & -0.014 & $-0.062^{* * *}$ & -0.023 & -0.036 & 0.045 & 0.024 & $-0.078^{* *}$ & $-0.086^{* *}$ & 0.015 & -0.017 & $-0.097^{* * *}$ & $-0.103^{* * *}$ \\
\hline \multicolumn{13}{|c|}{ B. Service } \\
\hline \multicolumn{13}{|c|}{ Above-median firms } \\
\hline$R O A$ & 0.023 & $0.102^{* * *}$ & $0.052 *$ & $0.091^{* * *}$ & 0.038 & $0.126^{* * *}$ & $0.114^{* * *}$ & $0.154^{* * *}$ & 0.033 & $0.094^{* *}$ & 0.052 & $0.091 * *$ \\
\hline$R O E$ & -0.036 & $0.102^{* * *}$ & 0.015 & $0.062 * *$ & -0.036 & $0.110^{* *}$ & -0.023 & 0.018 & $-0.076^{*}$ & 0.008 & $-0.120 * * *$ & $-0.070 *$ \\
\hline$C R$ & -0.037 & -0.006 & -0.003 & -0.013 & -0.030 & -0.044 & -0.021 & -0.039 & 0.032 & 0.052 & -0.061 & -0.050 \\
\hline \multicolumn{13}{|c|}{ Below-median firms } \\
\hline$R O A$ & $-0.054 *$ & $-0.056^{*}$ & $0.396^{* * *}$ & $0.363^{* * *}$ & 0.002 & $0.121^{* * *}$ & $0.301^{* * *}$ & $0.322 * * *$ & $-0.078 *$ & $-0.149^{* * *}$ & $0.365^{* * *}$ & $0.357^{* * *}$ \\
\hline$R O E$ & 0.008 & $0.049 *$ & 0.019 & 0.034 & 0.040 & $0.174^{* * *}$ & $-0.075^{*}$ & 0.021 & -0.004 & -0.040 & -0.050 & -0.049 \\
\hline$C R$ & -0.039 & $-0.123^{* * *}$ & 0.027 & 0.006 & -0.058 & $-0.121^{* * *}$ & -0.018 & -0.026 & 0.021 & $-0.084 *$ & -0.026 & -0.014 \\
\hline \multicolumn{13}{|c|}{ C. Diversified } \\
\hline \multicolumn{13}{|c|}{ Above-median firms } \\
\hline$R O A$ & -0.087 & -0.069 & 0.019 & 0.009 & -0.256 & -0.333 & 0.128 & 0.026 & -0.170 & -0.129 & -0.102 & 0.111 \\
\hline$R O E$ & $-0.332^{* * *}$ & 0.059 & $-0.158 *$ & 0.051 & $-0.410 *$ & -0.128 & -0.333 & -0.308 & $-0.323^{* * *}$ & 0.154 & $-0.229 * *$ & 0.114 \\
\hline$C R$ & $-0.272^{* * *}$ & -0.125 & $-0.327^{* * *}$ & -0.143 & -0.205 & -0.103 & -0.103 & -0.154 & $-0.235^{* *}$ & -0.035 & 0.029 & 0.003 \\
\hline
\end{tabular}


Table 4. Cont

\begin{tabular}{|c|c|c|c|c|c|c|c|c|c|c|c|c|}
\hline & \multicolumn{4}{|c|}{ Overall } & \multicolumn{4}{|c|}{ Developed } & \multicolumn{4}{|c|}{ Emerging } \\
\hline \multicolumn{13}{|c|}{ Below-median firms } \\
\hline$R O A$ & $-0.186^{*}$ & 0.037 & -0.141 & 0.046 & 0.209 & 0.143 & -0.275 & -0.231 & $-0.192 *$ & 0.122 & 0.038 & 0.086 \\
\hline$R O E$ & -0.148 & 0.016 & -0.091 & 0.002 & -0.143 & -0.033 & $-0.341 *$ & $-0.407^{* *}$ & -0.145 & 0.030 & -0.038 & -0.035 \\
\hline$C R$ & -0.134 & -0.098 & -0.078 & -0.125 & -0.143 & 0.099 & $-0.407^{* *}$ & $-0.385^{*}$ & -0.069 & -0.117 & -0.177 & -0.180 \\
\hline \multicolumn{13}{|c|}{ C1. Diversified-related } \\
\hline \multicolumn{13}{|c|}{ Above-median firms } \\
\hline$R O A$ & -0.020 & -0.014 & -0.060 & 0.037 & $0.500 *$ & $0.500 *$ & -0.143 & 0.000 & $-0.355^{* *}$ & $-0.368^{* *}$ & -0.190 & -0.190 \\
\hline ROE & -0.210 & 0.056 & $-0.225^{*}$ & 0.045 & -0.056 & $0.722 * * *$ & -0.333 & -0.278 & $-0.303 *$ & $-0.289 *$ & $-0.516^{* * *}$ & $-0.294 *$ \\
\hline$C R$ & $-0.217^{*}$ & -0.169 & $-0.280^{* *}$ & $-0.222 *$ & -0.167 & 0.000 & -0.111 & 0.000 & -0.229 & -0.124 & -0.242 & -0.281 * \\
\hline \multicolumn{13}{|c|}{ Below-median firms } \\
\hline$R O A$ & -0.084 & 0.119 & -0.084 & 0.163 & 0.244 & 0.244 & $-0.511^{* *}$ & $-0.467 *$ & 0.066 & $0.434^{* *}$ & 0.124 & 0.190 \\
\hline$R O E$ & -0.008 & 0.220 & 0.040 & 0.215 & 0.111 & -0.056 & -0.333 & -0.333 & 0.145 & $0.485^{* * *}$ & 0.072 & 0.137 \\
\hline$C R$ & $-0.319^{* *}$ & -0.138 & $-0.319^{* *}$ & -0.154 & $-0.611^{* *}$ & -0.333 & -0.222 & -0.222 & -0.160 & -0.041 & -0.076 & -0.099 \\
\hline \multicolumn{13}{|c|}{ C2. Diversified-unrelated } \\
\hline \multicolumn{13}{|c|}{ Above-median firms } \\
\hline$R O A$ & -0.203 & -0.152 & -0.203 & -0.143 & 0.600 & 0.400 & 0.200 & 0.000 & -0.085 & -0.033 & -0.085 & 0.163 \\
\hline$R O E$ & $-0.377^{* *}$ & -0.022 & $-0.429^{* * *}$ & -0.048 & 0.000 & $-1.000^{* * *}$ & -0.667 & $-1.000^{* * *}$ & $-0.373^{* *}$ & 0.294 * & -0.163 & $0.425^{* *}$ \\
\hline$C R$ & $-0.333^{* *}$ & -0.074 & $-0.333^{* *}$ & -0.100 & -0.333 & -0.333 & 0.667 & 0.667 & $-0.333^{*}$ & -0.072 & 0.190 & 0.203 \\
\hline \multicolumn{13}{|c|}{ Below-median firms } \\
\hline$R O A$ & $-0.352^{* *}$ & -0.178 & $-0.352^{* *}$ & -0.194 & -0.667 & $-1.000^{* * *}$ & 0.000 & 0.000 & $-0.451^{* * *}$ & -0.190 & 0.020 & 0.033 \\
\hline$R O E$ & $-0.336^{* *}$ & -0.273 * & -0.217 & $-0.328^{* *}$ & -0.400 & -0.400 & -0.200 & $-0.800^{* *}$ & $-0.425^{* *}$ & -0.333 * & -0.176 & -0.229 \\
\hline$C R$ & -0.138 & -0.012 & 0.138 & -0.051 & 0.600 & $0.800^{* *}$ & -0.600 & -0.600 & 0.150 & -0.020 & -0.255 & $-0.307^{*}$ \\
\hline
\end{tabular}

*** Correlation is significant at the 0.01 level (2-tailed). ${ }^{* *}$ Correlation is significant at the 0.05 level (2-tailed). ${ }^{*}$ Correlation is significant at the 0.10 level (2-tailed). 
Table 5. Kendall's correlation results. This table provides Kendall's $\tau$ correlation results for the overall sample of 2666 firms partition-wise (i.e., size, age, leverage and liquidity (which are instrumental/control variables here)). First, all such firms are divided into above- and below-median firms based on cross-sectional median values of each of these control variables. Thus, this study obtains large and small firms (size-partitions), old and young firms (age-partitions), high-leverage and low-leverage firms (leverage-partitions) and high-liquidity and low-liquidity firms [liquidity-partitions]. After that, we sub-divide all such partitions-firms into aboveand below-median firms based on cross-sectional median values of returns measures. We calculate for 1-year and 5-year time periods on a rolling basis.

\begin{tabular}{|c|c|c|c|c|c|c|c|c|c|c|c|c|}
\hline & \multicolumn{4}{|c|}{ Overall } & \multicolumn{4}{|c|}{ Developed } & \multicolumn{4}{|c|}{ Emerging } \\
\hline \multicolumn{13}{|c|}{ A. Size-partitions } \\
\hline \multicolumn{13}{|c|}{ A1. Large } \\
\hline \multicolumn{13}{|c|}{ Above-median firms } \\
\hline Variables & $F T R_{1}$ year & $F T R_{5}$ years & $I T R_{1}$ year & $I T R_{5}$ years & $F T R_{1}$ year & $F T R_{5}$ years & $I T R_{1}$ year & $I T R_{5}$ years & $F T R_{1}$ year & $F T R_{5}$ years & $I T R_{1}$ year & $I T R_{5}$ years \\
\hline$R O A$ & -0.019 & $0.043^{*}$ & 0.003 & $0.053^{* *}$ & $-0.103^{* * *}$ & -0.001 & $0.100^{* * *}$ & $0.148^{* * *}$ & 0.027 & $0.067 *$ & $0.065^{*}$ & $0.119^{* * *}$ \\
\hline$R O E$ & $-0.121^{* * *}$ & $0.064 * *$ & -0.037 & 0.017 & $-0.122 * * *$ & $0.107^{* * *}$ & $-0.095^{* *}$ & 0.000 & $-0.130 * * *$ & 0.064 * & $-0.060 *$ & -0.007 \\
\hline$C R$ & $-0.067^{* * *}$ & -0.031 & -0.009 & -0.003 & $-0.077^{* *}$ & $-0.075^{*}$ & -0.057 & $-0.077^{* *}$ & -0.056 & -0.012 & 0.030 & 0.040 \\
\hline \multicolumn{13}{|c|}{ Below-median firms } \\
\hline$R O A$ & $-0.104^{* * *}$ & -0.027 & $.312^{* * *}$ & $0.291^{* * *}$ & 0.019 & $0.120^{* * *}$ & $0.202^{* * *}$ & $0.213^{* * *}$ & $-0.149^{* * *}$ & $-0.090^{* * *}$ & $0.285^{* * *}$ & $0.260^{* * *}$ \\
\hline$R O E$ & $-0.082^{* * *}$ & 0.001 & $-0.082^{* * *}$ & $-0.051^{* *}$ & -0.061 & $0.086^{* *}$ & -0.063 & 0.001 & $-0.073^{* *}$ & $-0.066^{*}$ & $-0.102^{* * *}$ & $-0.092^{* * *}$ \\
\hline$C R$ & $-0.074^{* * *}$ & $-0.127^{* * *}$ & -0.018 & -0.036 & -0.006 & $-0.084^{* *}$ & -0.038 & -0.046 & -0.017 & -0.055 & 0.003 & 0.020 \\
\hline \multicolumn{13}{|c|}{ A2. Small } \\
\hline \multicolumn{13}{|c|}{ Above-median firms } \\
\hline$R O A$ & 0.033 & $0.112 * * *$ & -0.004 & $0.054^{* *}$ & 0.036 & $0.107^{* * *}$ & $0.125^{* * *}$ & $0.145^{* * *}$ & 0.001 & $0.123^{* * *}$ & $0.064 *$ & $0.117^{* * *}$ \\
\hline$R O E$ & $-0.075^{* * *}$ & $0.081^{* * *}$ & $-0.065^{* *}$ & 0.001 & $-0.064^{*}$ & $0.092^{* *}$ & -0.055 & 0.004 & $-0.095^{* * *}$ & $0.065 *$ & -0.030 & 0.011 \\
\hline$C R$ & 0.026 & $0.069^{* * *}$ & 0.010 & 0.038 & -0.020 & 0.021 & -0.027 & -0.020 & 0.046 & 0.045 & $-0.060 *$ & $-0.068^{*}$ \\
\hline \multicolumn{13}{|c|}{ Below-median firms } \\
\hline$R O A$ & $0.052 * *$ & $0.079^{* * *}$ & -0.014 & $0.049 *$ & $0.081^{* *}$ & $0.093^{* *}$ & $0.123^{* * *}$ & $0.181^{* * *}$ & $0.059 *$ & 0.052 & 0.029 & 0.053 \\
\hline$R O E$ & $0.104^{* * *}$ & $0.056^{* *}$ & $-0.058^{* *}$ & -0.001 & $0.101^{* * *}$ & $0.131^{* * *}$ & $-0.085^{* *}$ & 0.001 & $0.123^{* * *}$ & -0.001 & 0.000 & 0.023 \\
\hline$C R$ & 0.022 & -0.033 & -0.018 & -0.027 & $0.076^{* *}$ & $0.066^{*}$ & -0.060 & -0.060 & 0.010 & -0.043 & $-0.165^{* * *}$ & $-0.172^{* * *}$ \\
\hline
\end{tabular}


Table 5. Cont

\begin{tabular}{|c|c|c|c|c|c|c|c|c|c|c|c|c|}
\hline & \multicolumn{4}{|c|}{ Overall } & \multicolumn{4}{|c|}{ Developed } & \multicolumn{4}{|c|}{ Emerging } \\
\hline \multicolumn{13}{|c|}{ B. Age-partitions } \\
\hline \multicolumn{13}{|c|}{ B1. Old } \\
\hline \multicolumn{13}{|c|}{ Above-median firms } \\
\hline$R O A$ & 0.003 & $0.074^{* * *}$ & -0.033 & 0.033 & 0.039 & $0.092^{* *}$ & $0.110^{* * *}$ & $0.176^{* * *}$ & 0.034 & $0.080^{* *}$ & 0.043 & $0.110^{* * *}$ \\
\hline$R O E$ & $-0.099^{* * *}$ & $0.083^{* * *}$ & $-0.054^{* *}$ & 0.018 & $-0.087^{* *}$ & $0.100^{* * *}$ & $-0.130 * * *$ & -0.013 & $-0.069^{* *}$ & $0.070^{* *}$ & $-0.064 *$ & -0.002 \\
\hline$C R$ & 0.022 & $0.063^{* *}$ & -0.003 & 0.029 & 0.025 & 0.041 & $-0.079^{* *}$ & $-0.077^{* *}$ & 0.006 & 0.052 & 0.011 & 0.019 \\
\hline \multicolumn{13}{|c|}{ Below-median firms } \\
\hline$R O A$ & -0.026 & -0.011 & $0.259 * * *$ & $0.243^{* * *}$ & -0.017 & 0.049 & $0.134^{* * *}$ & $0.121^{* * *}$ & $-0.095^{* * *}$ & $-0.077^{* *}$ & $0.251^{* * *}$ & $0.241^{* * *}$ \\
\hline$R O E$ & -0.011 & $0.045 *$ & $-0.118^{* * *}$ & -0.050 * & 0.001 & $0.119^{* * *}$ & -0.050 & 0.007 & $-0.066^{*}$ & -0.051 & $-0.095^{* * *}$ & -0.052 \\
\hline$C R$ & $-0.081^{* * *}$ & $-0.144^{* * *}$ & 0.007 & -0.024 & -0.030 & $-0.091^{* *}$ & -0.062 & $-0.066^{*}$ & 0.000 & $-0.085^{* *}$ & -0.002 & 0.020 \\
\hline \multicolumn{13}{|c|}{ B2. Young } \\
\hline \multicolumn{13}{|c|}{ Above-median firms } \\
\hline$R O A$ & -0.003 & $0.086^{* * *}$ & $0.048^{*}$ & $0.084^{* * *}$ & -0.037 & 0.055 & $0.123^{* * *}$ & $0.147^{* * *}$ & -0.012 & $0.102^{* * *}$ & $0.082 * *$ & $0.129 * * *$ \\
\hline$R O E$ & $-0.108^{* * *}$ & $0.051^{* *}$ & -0.023 & 0.011 & -0.074 & $0.093^{* *}$ & -0.026 & 0.016 & $-0.121^{* * *}$ & 0.033 & -0.047 & -0.008 \\
\hline$C R$ & -0.033 & 0.003 & 0.015 & 0.020 & -0.013 & 0.011 & 0.017 & 0.010 & -0.029 & -0.004 & -0.032 & -0.044 \\
\hline \multicolumn{13}{|c|}{ Below-median firms } \\
\hline$R O A$ & -0.025 & -0.020 & $0.107^{* * *}$ & $0.138^{* * *}$ & 0.032 & 0.048 & $0.186^{* * *}$ & $0.233^{* * *}$ & 0.007 & -0.015 & $0.079 * *$ & $0.085^{* *}$ \\
\hline$R O E$ & $0.072^{* * *}$ & 0.036 & -0.040 & 0.004 & 0.052 & $0.104^{* * *}$ & $-0.110^{* * *}$ & -0.014 & $0.112^{* * *}$ & -0.010 & -0.001 & -0.007 \\
\hline$C R$ & 0.026 & -0.028 & -0.003 & -0.003 & 0.019 & -0.002 & -0.025 & -0.041 & 0.025 & -0.017 & $-0.145^{* * *}$ & $-0.148^{* * *}$ \\
\hline \multicolumn{13}{|c|}{ C. Leverage-partitions } \\
\hline \multicolumn{13}{|c|}{ C1. High-leverage } \\
\hline \multicolumn{13}{|c|}{ Above-median firms } \\
\hline$R O A$ & 0.022 & $0.105^{* * *}$ & -0.015 & $0.055^{* *}$ & 0.048 & $0.129^{* * *}$ & $0.118^{* * *}$ & $0.203^{* * *}$ & 0.005 & $0.084^{* *}$ & $0.128^{* * *}$ & $0.148^{* * *}$ \\
\hline$R O E$ & $-0.105^{* * *}$ & $0.120^{* * *}$ & -0.026 & $0.066^{* * *}$ & -0.062 & $0.116^{* * *}$ & $-0.095^{* *}$ & -0.016 & $-0.136^{* * *}$ & $0.073^{* *}$ & $-0.069^{* *}$ & -0.003 \\
\hline$C R$ & -0.035 & -0.014 & -0.035 & -0.022 & -0.057 & -0.038 & -0.027 & -0.038 & 0.011 & 0.010 & -0.053 & $-0.067^{*}$ \\
\hline
\end{tabular}


Table 5. Cont

\begin{tabular}{|c|c|c|c|c|c|c|c|c|c|c|c|c|}
\hline & \multicolumn{4}{|c|}{ Overall } & \multicolumn{4}{|c|}{ Developed } & \multicolumn{4}{|c|}{ Emerging } \\
\hline \multicolumn{13}{|c|}{ Below-median firms } \\
\hline$R O A$ & $-0.057^{* *}$ & $-0.053^{* *}$ & $0.078^{* * *}$ & $0.071^{* * *}$ & -0.031 & -0.034 & $0.096^{* *}$ & $0.123^{* * *}$ & 0.004 & 0.019 & $0.100^{* * *}$ & $0.089^{* *}$ \\
\hline$R O E$ & $0.062 * *$ & 0.026 & -0.012 & 0.014 & 0.024 & $0.082^{* *}$ & $-0.079 * *$ & -0.018 & $0.092^{* * *}$ & 0.011 & -0.017 & -0.017 \\
\hline$C R$ & 0.008 & $-0.078^{* * *}$ & 0.004 & -0.011 & 0.045 & -0.028 & $-0.069 *$ & $-0.073 *$ & 0.053 & -0.019 & $-0.126^{* * *}$ & $-0.120^{* * *}$ \\
\hline \multicolumn{13}{|c|}{ C2. Low-leverage } \\
\hline \multicolumn{13}{|c|}{ Above-median firms } \\
\hline$R O A$ & -0.021 & $0.046^{*}$ & 0.005 & 0.037 & -0.017 & 0.048 & $0.118^{* * *}$ & $0.132^{* * *}$ & 0.014 & $0.084^{* *}$ & 0.041 & $0.120^{* * *}$ \\
\hline$R O E$ & $-0.090 * * *$ & 0.042 & $-0.049 *$ & -0.012 & $-0.105^{* * *}$ & 0.061 & -0.053 & 0.005 & $-0.079^{* *}$ & 0.033 & -0.040 & 0.011 \\
\hline$C R$ & 0.028 & $0.077^{* * *}$ & 0.011 & 0.041 & 0.044 & $0.078^{* *}$ & -0.043 & -0.033 & -0.024 & 0.037 & 0.002 & 0.024 \\
\hline \multicolumn{13}{|c|}{ Below-median firms } \\
\hline$R O A$ & -0.012 & -0.021 & $0.268^{* * *}$ & $0.279 * * *$ & 0.003 & $0.083^{* *}$ & $0.205^{* * *}$ & $0.215^{* * *}$ & -0.055 & $-0.095^{* * *}$ & $0.211^{* * *}$ & $0.227^{* * *}$ \\
\hline$R O E$ & -0.007 & 0.026 & $-0.114^{* * *}$ & $-0.063^{* *}$ & 0.012 & $0.134^{* * *}$ & $-0.066^{*}$ & 0.029 & -0.009 & -0.049 & $-0.069 * *$ & $-0.059 *$ \\
\hline$C R$ & $-0.070^{* * *}$ & $-0.098^{* * *}$ & $0.046^{*}$ & 0.025 & -0.020 & -0.026 & -0.052 & -0.059 & -0.025 & $-0.072 * *$ & 0.014 & 0.010 \\
\hline \multicolumn{13}{|c|}{ D. Liquidity-partitions } \\
\hline \multicolumn{13}{|c|}{ D1. High-liquidity } \\
\hline \multicolumn{13}{|c|}{ Above-median firms } \\
\hline$R O A$ & -0.029 & 0.032 & 0.013 & $0.046^{*}$ & $-0.067 *$ & 0.036 & $0.105^{* * *}$ & $0.135^{* * *}$ & 0.002 & 0.035 & $0.075^{* *}$ & $0.120 * * *$ \\
\hline$R O E$ & $-0.116^{* *}$ & $0.068^{* * *}$ & $-0.059^{* *}$ & -0.001 & $-0.094^{* *}$ & $0.148^{* * *}$ & $-0.109^{* * *}$ & -0.023 & $-0.109 * * *$ & 0.029 & -0.055 & -0.015 \\
\hline$C R$ & $-0.068^{* * *}$ & -0.026 & -0.009 & -0.005 & -0.017 & -0.014 & -0.026 & -0.040 & $-0.087^{* *}$ & -0.046 & -0.016 & 0.002 \\
\hline \multicolumn{13}{|c|}{ Below-median firms } \\
\hline$R O A$ & $-0.065^{* *}$ & 0.004 & $0.319^{* * *}$ & $0.303^{* * *}$ & 0.025 & $0.129 * * *$ & $0.210^{* * * *}$ & $0.221^{* * *}$ & $-0.108^{* * *}$ & $-0.083^{* *}$ & $0.257^{* * *}$ & $0.248^{* * *}$ \\
\hline$R O E$ & $-0.048^{*}$ & 0.023 & $-0.061^{* *}$ & -0.025 & -0.048 & $0.114^{* * *}$ & -0.029 & 0.024 & -0.045 & $-0.069^{* *}$ & $-0.074^{* *}$ & $-0.065^{*}$ \\
\hline$C R$ & $-0.069 * * *$ & $-0.120^{* * *}$ & -0.023 & -0.036 & -0.018 & $-0.080 * *$ & -0.063 & $-0.073 *$ & 0.005 & -0.049 & 0.009 & 0.021 \\
\hline
\end{tabular}


Table 5. Cont.

\begin{tabular}{|c|c|c|c|c|c|c|c|c|c|c|c|c|}
\hline & \multicolumn{4}{|c|}{ Overall } & \multicolumn{4}{|c|}{ Developed } & \multicolumn{4}{|c|}{ Emerging } \\
\hline \multicolumn{13}{|c|}{ D2. Low-liquidity } \\
\hline \multicolumn{13}{|c|}{ Above-median firms } \\
\hline$R O A$ & 0.036 & $0.118^{* * *}$ & -0.021 & $0.052 * *$ & -0.001 & $0.085^{* *}$ & $0.117^{* * *}$ & $0.158^{* * *}$ & 0.013 & $0.153^{* * *}$ & $0.086^{* *}$ & $0.150 * * *$ \\
\hline$R O E$ & $-0.084^{* * *}$ & $0.072^{* * *}$ & -0.042 & 0.021 & $-0.075^{*}$ & $0.068 *$ & -0.033 & 0.030 & $-0.127^{* * *}$ & $0.095^{* * *}$ & -0.047 & 0.023 \\
\hline$C R$ & 0.035 & $0.078^{* * *}$ & 0.018 & $0.050 *$ & -0.036 & 0.009 & -0.002 & -0.003 & 0.046 & $0.061 *$ & -0.033 & -0.052 \\
\hline \multicolumn{13}{|c|}{ Below-median firms } \\
\hline$R O A$ & 0.011 & 0.024 & 0.006 & $0.051^{* *}$ & $0.063 *$ & 0.048 & $0.116^{* * *}$ & $0.171^{* * *}$ & 0.033 & 0.030 & 0.048 & 0.055 \\
\hline$R O E$ & $0.085^{* * *}$ & $0.042 *$ & $-0.066^{* *}$ & -0.014 & $0.100^{* * *}$ & $0.106^{* * *}$ & $-0.123^{* * *}$ & -0.029 & $0.096^{* * *}$ & -0.004 & -0.009 & 0.005 \\
\hline$C R$ & 0.016 & $-0.049 *$ & 0.035 & 0.015 & 0.048 & 0.022 & -0.057 & -0.060 & 0.004 & -0.042 & $-0.140^{* * *}$ & $-0.140^{* * *}$ \\
\hline
\end{tabular}

${ }^{* * *}$ Correlation is significant at the 0.01 level (2-tailed). ${ }^{* *}$ Correlation is significant at the 0.05 level (2-tailed). ${ }^{*}$ Correlation is significant at the 0.10 level (2-tailed). 
Table 5 shows that manufacturing (old economy) firms across overall, developed and emerging countries cases are validating Hypotheses 1 and 2, but rejecting Hypothesis 5. This is because below-median (poor) manufacturing firms are risk seeking as they show a "paradoxical" risk-return association. On the other hand, the service (new economy) firms of emerging countries are only supporting Hypothesis 4. Developed countries service firms are risk averse across poor-to-superior cases. Therefore, we validate Hypothesis 4 only partially.

From Table 5, we infer that both above- and below-median diversified firms are showing significant negative risk-return association and thereby risk-seeking attitude across countries. This is because both related and unrelated such firms are supporting the overall results in showing a "paradoxical" risk-return association. Accordingly, these results reject Hypothesis 3.1 and accepts Hypothesis 3.2 as suggested by empirical literature and examined under this study.

Table 5 presents partitions results for superior and poor firms across countries. It is interesting to note that most large firms (except poor firms of developed countries) are showing significant negative (i.e., "paradoxical") risk-return association which implies that they are risk seeking. On the other hand, results show a risk-averse attitude of small firms with mostly (except poor firms from emerging countries) significant conventional positive risk-return relationship. Both old and young above-median firms are risk-averse. This is true in cases of below-median firms also except poor firms from emerging countries that are risk seeking (i.e., a "paradoxical" relationship). Thus, we partially validate Hypotheses 1 and 2 under both "market power" proxies. Low-leverage firms (for obvious reasons), and both highand low-liquidity firms (except poor firms from emerging countries) also show risk-averse attitude in the overall study period. Thus, we also partially validate Hypotheses 1 and 2.

\subsubsection{Kendall's Correlation Results—Bull and Bear Sub-Periods}

Table 6 shows Kendall's correlation results for overall sample during bull and bear sub-periods. ${ }^{10}$ Below-median firms are showing a "paradoxical" risk-return association in bear sub-periods only under all return measures and across developed and emerging countries. However, in bull sub-periods they are risk-averse across countries which contradict the notion that poor firms (or troubled ones (Bowman 1980)) are always risk seeking. This clearly implies that strong bull market cycles influence poor firms' risk-taking in a conservative way. However, above-median firms are risk averse in both bull and bear sub-periods across developed and emerging countries, and thereby validate Hypothesis 2 .

It is interesting to note that in bear sub-periods both above- and below-median related diversified firms show negative risk-return association, which implies their risk-seeking attitude in those periods across countries. Therefore, we accept Hypothesis 3.2 for related firms in such periods. This is in line with earlier overall results for these firms. In bear sub-periods, poor manufacturing firms become extremely risk seeking (as negative correlation coefficient values are high) as the market trend is not favorable. The poor service firms also show similar results. These results reject Hypothesis 5 and accept Hypothesis 4 for manufacturing and service firms, respectively. These results are true in bear sub-periods across developed and emerging countries firms, but in the bull sub-periods superior performers across countries are significantly and overwhelmingly showing a risk-averse attitude always in both industry and firm's own performance-adjusted target returns, both in the short- and long-term. We interpret from the results that irrespective of industry-nature or competition, poor firms are always risk seeking whereas superior ones are risk-averse in both sub-periods especially in bull sub-periods. In addition, in bear sub-periods there can be a market cycles' impact, which can make superior performers also act as risk-seeking, especially emerging countries' firms.

10 Bull and bear sub-periods results for the industry-classified and partitions wise sub-samples are also calculated and discussed in this sub-section, but we do not show relevant tables here for brevity. 
Table 6. Kendall's correlation results. This table provides Kendall's $\tau$ correlation results for the overall sample of 2666 firms (1199 firms from 15 developed countries and 1467 firms from 12 emerging countries) after dividing them in above- and below-median firms based on cross-sectional median values in bull and bear sub-periods. We calculate for 1-year and 5-year time periods on a rolling basis.

\begin{tabular}{|c|c|c|c|c|c|c|c|c|c|c|c|c|}
\hline & \multicolumn{4}{|c|}{ Overall } & \multicolumn{4}{|c|}{ Developed } & \multicolumn{4}{|c|}{ Emerging } \\
\hline \multicolumn{13}{|c|}{ A. Bull periods } \\
\hline \multicolumn{13}{|c|}{ Above-median firms } \\
\hline Variables & $F T R_{1}$ year & $F T R_{5}$ years & $I T R_{1}$ year & $I T R_{5}$ years & $F T R_{1}$ year & $F T R_{5}$ years & $I T R_{1}$ year & $I T R_{5}$ years & $F T R_{1}$ year & $F T R_{5}$ years & $I T R_{1}$ year & $I T R_{5}$ years \\
\hline$R O A$ & $0.077^{* * *}$ & $0.103^{* * *}$ & -0.028 & -0.001 & $0.058^{* *}$ & $0.079^{* * *}$ & $-0.055^{* *}$ & $-0.055^{* *}$ & $0.085^{* * *}$ & $0.129^{* * *}$ & -0.008 & $0.046^{*}$ \\
\hline$R O E$ & $0.049^{* * *}$ & $0.085^{* * *}$ & -0.028 & -0.013 & 0.027 & 0.043 & -0.001 & -0.015 & $0.052 * *$ & $0.113^{* * *}$ & $-0.052^{* *}$ & -0.013 \\
\hline$C R$ & 0.005 & $0.036 *$ & -0.005 & 0.002 & -0.008 & 0.041 & 0.010 & 0.006 & 0.001 & 0.016 & -0.023 & -0.016 \\
\hline \multicolumn{13}{|c|}{ Below-median firms } \\
\hline$R O A$ & $0.072 * * *$ & $0.036^{* *}$ & $0.076^{* * *}$ & $0.052 * * *$ & $0.070^{* * *}$ & $0.070 * *$ & 0.031 & 0.015 & $0.079^{* * *}$ & 0.023 & $0.109^{* * *}$ & $0.085^{* * *}$ \\
\hline$R O E$ & $0.066^{* * *}$ & $0.062^{* * *}$ & -0.003 & -0.008 & $0.107^{* * *}$ & $0.158^{* * *}$ & 0.011 & -0.014 & $0.045^{*}$ & -0.008 & -0.005 & 0.005 \\
\hline$C R$ & 0.017 & -0.012 & $0.043^{* *}$ & 0.018 & 0.039 & -0.013 & 0.001 & -0.017 & 0.012 & 0.012 & 0.004 & -0.012 \\
\hline \multicolumn{13}{|c|}{ B. Bear periods } \\
\hline \multicolumn{13}{|c|}{ Above-median firms } \\
\hline$R O A$ & $-0.031 *$ & $0.063^{* * *}$ & 0.014 & 0.016 & -0.004 & $0.093^{* * *}$ & -0.009 & 0.003 & $-0.053^{* *}$ & $0.046^{*}$ & $0.052 * *$ & $0.046^{*}$ \\
\hline$R O E$ & -0.009 & $0.057^{* * *}$ & -0.002 & 0.003 & 0.017 & $0.089^{* * *}$ & -0.008 & -0.023 & $-0.048^{*}$ & 0.018 & -0.016 & 0.004 \\
\hline$C R$ & $0.046^{* *}$ & 0.021 & 0.027 & 0.021 & $0.045^{*}$ & 0.031 & 0.013 & 0.027 & 0.030 & 0.019 & $0.045^{*}$ & 0.039 \\
\hline \multicolumn{13}{|c|}{ Below-median firms } \\
\hline$R O A$ & $-0.146^{* * *}$ & $-0.069^{* * *}$ & -0.006 & -0.010 & $-0.097^{* * *}$ & -0.006 & $-0.064^{* *}$ & $-0.055^{* *}$ & $-0.175^{* * *}$ & $-0.111^{* * *}$ & 0.040 & 0.025 \\
\hline$R O E$ & $-0.101^{* * *}$ & $-0.059^{* * *}$ & -0.024 & -0.024 & -0.034 & 0.006 & -0.006 & -0.008 & $-0.147^{* * *}$ & $-0.105^{* * *}$ & -0.037 & -0.032 \\
\hline$C R$ & $-0.074^{* * *}$ & $-0.064^{* * *}$ & 0.014 & 0.006 & $-0.112^{* * *}$ & $-0.075^{* * *}$ & $-0.057^{* *}$ & $-0.073^{* * * *}$ & $-0.045^{*}$ & -0.039 & 0.039 & 0.034 \\
\hline
\end{tabular}


Partitions results in bear sub-periods are also not in line with the overall results for all firms, and for emerging market firms specifically. Results show that irrespective of "market power", during market downturns all such firms have to undertake a higher amount of risk to earn regular income. Thereby, in bear sub-periods, these firms significantly show a negative (i.e., "paradoxical") risk-return association, which implies their risk-seeking attitude in line with the standard PT implications. However, in bull sub-periods, partitions results across countries are in line with the overall results.

It is evident from the above discussion that most of the bull and bear sub-periods results do not substantiate overall study period's industry-classified and partitions wise findings across developed and emerging markets. So, it is inferred that the risk-return association and thereby risk attitude implications are impacted by external market trends or market cycles especially in bear sub-periods, and specifically for emerging countries firms.

\subsection{Multivariate Regression Results}

This section presents the multivariate regression results for the overall period and bull and bear sub-periods.

\subsubsection{Multivariate Regression Results—Overall Period}

Table 7 presents multivariate regression results for overall sample firms and developed and emerging countries firms. The poor firms across countries are showing a "paradoxical" risk-return association and thereby risk-seeking attitude whereas their above-median counterparts are risk averse under all results. In case of manufacturing firms, overall, developed and emerging countries firms, results are in line with earlier univariate results. However, in the case of service firms the results partially differ as both developed and emerging countries below-median firms show a risk-seeking attitude. The diversified firms' return impact on their risk-level are, however, not very conclusive. ${ }^{11}$ A firm's own past performance $F T R_{1}$ year and $F T R_{5}$ years are influencing firm's risk in most of the cases for manufacturing and service firms in the overall period across countries, for both superior and poor performers.

Partitions multivariate regression results are also in line with earlier univariate results. The risk-seeking nature of large firms with the exception of poor firms from developed countries and young and old poor ones from emerging countries, positive risk-return association of small firms except below-median firms of emerging countries and low-liquidity firms with exception of emerging countries poor firms, etc. all are evident in these results also.

11 Multivariate regression results of diversified (related and unrelated) and industry-classified firms are discussed in this sub-section, but relevant tables are not shown here for brevity purpose. We discuss such results for partitions sub-samples here but do not show for brevity purpose. 
Table 7. Multivariate regression results. This table provides multivariate regression results (see Equation (2)) for overall sample of 2666 firms after dividing them in above- and below-median firms based on cross-sectional median values. Here, ROA (risk) is the dependent variable and firm's return, distance $(D T)$ from firm-adjusted and industry-adjusted target returns are main and other independent variables. Here $R O A$ stands for return on assets, $R O E$ implies return on equity and $C R$ denotes cash ratio. In addition, FTR stands for firm-adjusted target return and ITR implies industry-adjusted target return. We calculate for 1 year and 5 years' time-periods on a rolling basis. In addition, the instrumental/control variables of size, age, leverage and liquidity are incorporated in the model. To make it more robust, dummy variables of related and unrelated diversified firms, financial services firms and country (emerging/developed) are also included. The table also shows the results pertaining to developed and emerging market firms separately.

\begin{tabular}{|c|c|c|c|c|c|c|c|}
\hline \multirow[t]{2}{*}{ Measures } & \multirow[t]{2}{*}{ Variables } & \multicolumn{2}{|c|}{ Overall } & \multicolumn{2}{|c|}{ Developed } & \multicolumn{2}{|c|}{ Emerging } \\
\hline & & Above & Below & Above & Below & Above & Below \\
\hline \multirow{8}{*}{$R O A$} & $R O A_{f, t}$ & $\begin{array}{c}0.125^{* * *} \\
(0.019)\end{array}$ & $\begin{array}{c}-0.864^{* * *} \\
(0.026)\end{array}$ & $\begin{array}{l}0.063 * \\
(0.033)\end{array}$ & $\begin{array}{c}-0.556^{* * *} \\
(0.035)\end{array}$ & $\begin{array}{c}0.198^{* * *} \\
(0.023)\end{array}$ & $\begin{array}{c}-1.005^{* * *} \\
(0.044)\end{array}$ \\
\hline & $\operatorname{DTFTR}_{1 \text { year }}$ & $\begin{array}{c}-1.746^{* * *} \\
(0.240)\end{array}$ & $\begin{array}{c}-1.240^{* * * *} \\
(0.292)\end{array}$ & $\begin{array}{c}-2.232 * * * \\
(0.320)\end{array}$ & $\begin{array}{c}-1.497^{* * *} \\
(0.440)\end{array}$ & $\begin{array}{c}0.032 \\
(0.380)\end{array}$ & $\begin{array}{c}-1.556^{* * *} \\
(0.372)\end{array}$ \\
\hline & $D_{T F T R}{ }_{5}$ years & $\begin{array}{c}1.520 * * * \\
(0.194)\end{array}$ & $\begin{array}{c}0.884^{* * *} \\
(0.271)\end{array}$ & $\begin{array}{c}2.193 * * * \\
(0.260)\end{array}$ & $\begin{array}{c}1.764^{* * *} \\
(0.389)\end{array}$ & $\begin{array}{l}-0.268 \\
(0.303)\end{array}$ & $\begin{array}{c}0.708 * * \\
(0.361)\end{array}$ \\
\hline & $D_{T I T R} 1_{\text {year }}$ & $\begin{array}{c}0.881 * * * \\
(0.194)\end{array}$ & $\begin{array}{c}0.312 \\
(0.272)\end{array}$ & $\begin{array}{c}1.300 * * * \\
(0.272)\end{array}$ & $\begin{array}{c}0.590 \\
(0.381)\end{array}$ & $\begin{array}{l}-0.313 \\
(0.281)\end{array}$ & $\begin{array}{c}0.107 \\
(0.351)\end{array}$ \\
\hline & $D_{T I T R} 5$ years & $\begin{array}{c}-0.926^{* * *} \\
(0.193)\end{array}$ & $\begin{array}{l}-0.213 \\
(0.272)\end{array}$ & $\begin{array}{c}-1.359^{* * * *} \\
(0.272)\end{array}$ & $\begin{array}{l}-0.599 \\
(0.380)\end{array}$ & $\begin{array}{c}0.267 \\
(0.279)\end{array}$ & $\begin{array}{c}0.049 \\
(0.354)\end{array}$ \\
\hline & $R^{2}$ & 0.176 & 0.528 & 0.289 & 0.616 & 0.136 & 0.568 \\
\hline & Adjusted $R^{2}$ & 0.169 & 0.523 & 0.274 & 0.608 & 0.122 & 0.561 \\
\hline & $F$ & $23.547^{* * *}$ & $122.836^{* * *}$ & $19.798^{* * *}$ & $78.674^{* * *}$ & $9.481^{* * *}$ & $78.958 * * *$ \\
\hline \multirow{9}{*}{$R O E$} & $R O E_{f, t}$ & $\begin{array}{c}-1.090^{* * * *} \\
(0.021)\end{array}$ & $\begin{array}{c}-1.090^{* * * *} \\
(0.034)\end{array}$ & $\begin{array}{c}0.388^{* * *} \\
(0.024)\end{array}$ & $\begin{array}{c}-0.585^{* * *} \\
(0.039)\end{array}$ & $\begin{array}{c}0.267^{* * *} \\
(0.037)\end{array}$ & $\begin{array}{c}-1.363^{* * *} \\
(0.045)\end{array}$ \\
\hline & $\operatorname{DTFTR}_{1}$ year & $\begin{array}{c}-1.080^{* * * *} \\
(0.129)\end{array}$ & $\begin{array}{c}-1.080^{* * *} \\
(0.062)\end{array}$ & $\begin{array}{c}-1.215^{* * * *} \\
(0.156)\end{array}$ & $\begin{array}{c}0.171 \\
(0.268)\end{array}$ & $\begin{array}{c}-1.297^{* * *} \\
(0.212)\end{array}$ & $\begin{array}{c}-0.950 \text { *** } \\
(0.077)\end{array}$ \\
\hline & $D_{T F T R}{ }_{5 \text { years }}$ & $\begin{array}{c}2.210^{* * *} \\
(0.057)\end{array}$ & $\begin{array}{c}2.210^{* * *} \\
(0.005)\end{array}$ & $\begin{array}{c}0.508^{* * *} \\
(0.073)\end{array}$ & $\begin{array}{l}0.449^{*} \\
(0.255)\end{array}$ & $\begin{array}{c}0.944^{* * *} \\
(0.086)\end{array}$ & $\begin{array}{c}2.206^{* * *} \\
(0.005)\end{array}$ \\
\hline & $D_{T I T R} 1$ year & $\begin{array}{c}-0.024^{* * *} \\
(0.072)\end{array}$ & $\begin{array}{l}-0.024 \\
(0.071)\end{array}$ & $\begin{array}{c}-0.232 * * \\
(0.094)\end{array}$ & $\begin{array}{l}-0.352 \\
(0.277)\end{array}$ & $\begin{array}{l}-0.115 \\
(0.107)\end{array}$ & $\begin{array}{c}0.120 \\
(0.090)\end{array}$ \\
\hline & & $0.006^{* *}$ & 0.006 & $0.006^{* *}$ & 0.254 & 0.006 & 0.004 \\
\hline & $D T T T R_{5}$ years & $(0.003)$ & $(0.005)$ & $(0.003)$ & $(0.280)$ & (0.005) & $(0.005)$ \\
\hline & $R^{2}$ & 0.378 & 0.538 & 0.513 & 0.407 & 0.292 & 0.558 \\
\hline & Adjusted $R^{2}$ & 0.372 & 0.525 & 0.503 & 0.395 & 0.280 & 0.541 \\
\hline & $F$ & $66.810^{* * *}$ & $78.003^{* * *}$ & $51.385^{* * *}$ & $33.546^{* * *}$ & $24.740^{* * *}$ & $72.89 * * *$ \\
\hline \multirow{11}{*}{$C R$} & $C R_{f, t}$ & $\begin{array}{c}1.217^{* * * *} \\
(0.012)\end{array}$ & $\begin{array}{c}-0.970^{* * * *} \\
(0.020)\end{array}$ & $\begin{array}{c}0.342 * * * \\
(0.027)\end{array}$ & $\begin{array}{c}-0.335^{* * *} \\
(0.038)\end{array}$ & $\begin{array}{c}1.327^{* * * *} \\
(0.013)\end{array}$ & $\begin{array}{c}-1.045^{* * *} \\
(0.024)\end{array}$ \\
\hline & $D_{T F T R}{ }_{1}$ year & $\begin{array}{c}0.144 \\
(0.401)\end{array}$ & $\begin{array}{c}0.509 \\
(0.338)\end{array}$ & $\begin{array}{c}1.506^{* * *} \\
(0.361)\end{array}$ & $\begin{array}{c}-0.914^{* * *} \\
(0.346)\end{array}$ & $\begin{array}{c}-0.419 \\
(0.565)\end{array}$ & $\begin{array}{c}0.744 \\
(0.488)\end{array}$ \\
\hline & & -0.389 & -0.188 & -0.103 & $1.146^{* * *}$ & -0.353 & -0.309 \\
\hline & $D^{\prime} T F T R_{5}$ years & $(0.416)$ & $(0.322)$ & $(0.345)$ & $(0.277)$ & $(0.596)$ & $(0.481)$ \\
\hline & & $0.914^{* *}$ & 0.237 & -0.250 & $0.507^{* *}$ & $1.615^{* * *}$ & 0.338 \\
\hline & $D T I T R_{1}$ year & $(0.400)$ & $(0.275)$ & $(0.363)$ & $(0.247)$ & $(0.565)$ & $(0.403)$ \\
\hline & DTITR $_{5}$ years & $-1.101^{* *}$ & -0.248 & 0.185 & $-0.559^{* *}$ & $-1.810^{* * *}$ & -0.355 \\
\hline & $D T 11 R_{5}$ years & $(0.433)$ & $(0.303)$ & $(0.355)$ & $(0.270)$ & $(0.624)$ & $(0.444)$ \\
\hline & $R^{2}$ & 0.488 & 0.678 & 0.441 & 0.258 & 0.594 & 0.764 \\
\hline & Adjusted $R^{2}$ & 0.476 & 0.675 & 0.430 & 0.242 & 0.584 & 0.760 \\
\hline & $F$ & $92.521^{* * *}$ & $23.177^{* * *}$ & $42.055^{* * *}$ & $16.977^{* * *}$ & $94.109^{* * *}$ & $94.675^{* * *}$ \\
\hline
\end{tabular}

*** Correlation is significant at the 0.01 level (2-tailed). ${ }^{* *}$ Correlation is significant at the 0.05 level (2-tailed). * Correlation is significant at the 0.10 level (2-tailed).

\subsubsection{Multivariate Regression Results—Bull and Bear Sub-Periods}

Below-median firms are always risk seeking in bear sub-periods whereas in bull periods results are not very conclusive. However, superior firms are showing a risk-averse attitude across countries 
and across market cycles. Both poor manufacturing and service firms overall and from both developed and emerging countries are showing a "paradoxical" risk-return relationship (i.e., risk seeking) in bear sub-periods. Also, firm's own past performance-based $F T R_{1}$ year and $F T R_{5}$ years are influencing firm's risk in most of the cases for manufacturing and service firms across countries in bull and bear sub-periods for both superior and poor performers (in line with the overall period results). Bull sub-periods results are in tandem with univariate results. In addition, most of bull and bear sub-periods partitions wise results across countries are in line with above discussed overall period results. ${ }^{12}$

\subsection{Robustness Checks Results}

The robustness check results under first i.e., ROE measure (see all tables), second removing $5 \%$ outliers respectively from top and bottom firms and final i.e., without financial firms tests provide similar results as under univariate and multivariate cases. ${ }^{13}$ Results prove that poor firms across countries in the overall period and both in bull and bear sub-periods, and in overall sample and under all industry-classified and partitions wise sub-samples are risk seeking. Similarly, above-median (i.e., superior) firms are mostly risk-averse. However, like actual results, it is evident from robustness check results that in bear sub-periods, superior firms from emerging countries are also risk-seeking when they strive to achieve their past year(s) performance (i.e., FTR). It is also evident from overall robustness check results that firm's own past-performance-based (both short- and long-term) target returns are most appropriate in examining risk-return association and subsequent PT implications based on them.

Alternatively, we also verify if the multivariate regression results differ when Panel data regression is applied. We run both fixed and random effects model of regressions with same explanatory variables and controls for both $R O A$ and Cash ratio based risk measures. We run the panel data models separately for above median and below median values of these two measures of riskiness. The Hausman's test statistics in all cases recommend the use of fixed effects model as it reveals very high chi-square values with p-values lower than $1 \%$ implying the rejection of null hypothesis that random effects model is appropriate. We use firm, year and country fixed effects in the models along with the first lag of dependent variable to address the endogeneity issues, if any, in our dataset. Our regression results are in consistence with earlier estimation in terms of sign and significance, though smaller coefficients in magnitude terms are observed (estimates not reported for brevity but available on request), implying reliability of our reported empirical results. For example, $R O A$ for above and below median regression has a coefficient of $0.024(t=6.93)$ and $-0.015(t=-4.48)$ and this consistency prevails more or less across the estimates.

Table 8 reports the dynamic panel model results using system GMM estimation technique (used in line with Nenu et al. 2018; Wafa and Hédi 2018). The sign and significance of coefficients suggest that our results do not differ qualitatively from fixed effects, and reported multivariate regressions estimates, largely. These results, therefore, confirm our propositions strongly. Moreover, since GMM technique controls for endogeneity issues, the consistency of our results confirm that the reported relationship is not susceptible to endogeneity concerns in our sample data.

Thus, we confirm that our results are not susceptible to methods and measures employed.

12 We discuss multivariate regression results of all firms and emerging and developed countries firms in bull and bear sub-periods in this sub-section, but we do not show relevant tables here for brevity.

13 Robustness tests (except $R O E$ ) results are not shown here for brevity. 
Table 8. System GMM estimation results. This table explains the system GMM estimation results.

\begin{tabular}{|c|c|c|c|c|}
\hline & \multicolumn{2}{|c|}{$R O A S D$} & \multicolumn{2}{|c|}{$C R S D$} \\
\hline$R O A$ & $\begin{array}{l}\text { Above } \\
+* * *\end{array}$ & $\begin{array}{l}\text { Below } \\
+* * *\end{array}$ & Above & Below \\
\hline$C R$ & & & $+* * *$ & $-* * *$ \\
\hline $\operatorname{DTFTR}_{1 \text { year }}$ & $+* * *$ & $-* * *$ & - & $+* * *$ \\
\hline$D_{T F T R} 5$ years & $-{ }^{* * *}$ & $+* * *$ & $-* * *$ & $+* * *$ \\
\hline DTITR $_{1 \text { year }}$ & $+^{*}$ & - & + & + \\
\hline$D_{T I T R} 5$ years & - & + & - & + \\
\hline Size & $-* * *$ & $+* * *$ & + & $-* * *$ \\
\hline Age & $+* * *$ & - & $+* * *$ & $-* * *$ \\
\hline Liquidity & + & $+* * *$ & + & + \\
\hline Leverage & + & + & - & $-* * *$ \\
\hline L1.ROASD & $+* * *$ & $-* * *$ & $-* * *$ & \\
\hline L1.CRSD & & & $-* * *$ & $-* * *$ \\
\hline Constant & $-* * *$ & $+* * *$ & + & $+* * *$ \\
\hline
\end{tabular}

\section{Conclusions}

Our results provide evidence of variation in the risk-return association between emerging and developed countries across time-periods and market cycles. It is also evident that the PT implications are contingent on return measures used, in both firm- and industry-adjusted cases for 1-year (short-term) and 5-year (long-term) longitudinal studies. These substantiate earlier individual works of (Bae et al. 2012; Chou et al. 2009; Fiegenbaum and Thomas 1988, 2004; Díez-Estebana et al. 2017; Holder et al. 2016; Kliger and Tsur 2011; Li et al. 2013; etc.) in narrow contexts with a broad international context. Multiple robustness check results further authenticate the resulting generalizations here.

Our study results can motivate international investors to add this time-varying risk-return association in contexts while creating and modifying their portfolios. It is also advisable for them to investigate firm risk arising from operational uncertainties along with traditional systematic risks. These findings would also enable firms in different country contexts to revisit their investment and financial decision-making.

More representation internationally could make our study results more generalised. In addition, sub-period study during different economic cycles or crisis times can further strengthen our findings. In addition, future researchers can aim to find country-specific, time-specific and industry-specific determinants of the risk-return association and risk attitude that we derive here. The impact of corporate governance, accounting and stock markets regulations (strong vs. weak) on risk-return contexts can also be a research issue in the future.

Author Contributions: The research gaps, literature review and basic model development is done by the R.D.G. Methodological development and a thorough writing and style verification is done by R.P.

Funding: This research received no external funding.

Conflicts of Interest: The authors declare no conflicts of interest. 


\section{Appendix A}

Table A1. Descriptive statistic results. This table provides mean, maximum, minimum and standard deviation $(S D)$ statistics for above- and below-median firms for the overall period and bull and bear sub-periods (in \%). Additionally, we provide such results for industry-classified (i.e., manufacturing and service) firms.

\begin{tabular}{|c|c|c|c|c|c|c|c|c|c|c|c|c|}
\hline \multicolumn{13}{|c|}{ A. Overall Period-All Firms } \\
\hline \multicolumn{13}{|c|}{ A1. Above-median firms } \\
\hline \multicolumn{5}{|c|}{ Overall } & \multicolumn{4}{|c|}{ Developed } & \multicolumn{4}{|c|}{ Emerging } \\
\hline Variables & Min. & Max. & Mn. & $S D$ & Min. & Max. & Mn. & $S D$ & Min. & Max. & Mn. & $S D$ \\
\hline$R O A$ & 3.90 & 51.90 & 8.56 & 4.57 & 4.42 & 28.82 & 9.00 & 4.19 & 3.49 & 51.90 & 8.17 & 4.87 \\
\hline ROE & 11.19 & 328.58 & 20.16 & 14.20 & 12.06 & 328.58 & 21.88 & 17.26 & 10.26 & 158.34 & 18.69 & 10.95 \\
\hline$C R$ & 6.80 & 2486.09 & 15.21 & 69.45 & 8.32 & 65.88 & 14.19 & 5.94 & 5.27 & 2486.09 & 15.75 & 93.55 \\
\hline \multicolumn{13}{|c|}{ A2. Below-median firms } \\
\hline$R O A$ & -125.58 & 3.89 & 1.11 & 4.54 & -31.00 & 4.42 & 1.55 & 3.58 & -125.58 & 3.49 & 0.79 & 5.20 \\
\hline ROE & -547.27 & 11.18 & 3.20 & 17.49 & -81.83 & 12.04 & 5.74 & 7.36 & -547.27 & 10.25 & 1.21 & 22.44 \\
\hline$C R$ & -187.76 & 6.80 & 1.89 & 7.08 & -23.96 & 8.32 & 4.34 & 3.41 & -187.76 & 5.25 & 0.21 & 8.77 \\
\hline \multicolumn{13}{|c|}{ B. Bull periods-all firms } \\
\hline \multicolumn{13}{|c|}{ B1. Above-median firms } \\
\hline$R O A$ & 4.09 & 48.60 & 8.88 & 4.78 & 4.68 & 31.26 & 9.44 & 4.60 & 3.64 & 48.60 & 8.38 & 4.92 \\
\hline ROE & 11.61 & 260.58 & 21.19 & 13.27 & 12.63 & 260.58 & 23.23 & 15.87 & 10.69 & 165.30 & 19.44 & 10.47 \\
\hline$C R$ & 7.08 & 1718.33 & 15.25 & 53.18 & 8.29 & 63.24 & 14.46 & 6.43 & 5.47 & 1718.33 & 15.64 & 71.47 \\
\hline \multicolumn{13}{|c|}{ B2. Below-median firms } \\
\hline$R O A$ & -288.29 & 4.09 & 0.81 & 8.77 & -70.43 & 4.66 & 1.33 & 4.73 & -288.29 & 3.60 & 0.44 & 11.03 \\
\hline$R O E$ & -101.92 & 11.61 & 3.31 & 9.96 & -83.69 & 12.62 & 5.32 & 9.15 & -101.92 & 10.68 & 1.75 & 10.38 \\
\hline$C R$ & -244.31 & 7.08 & 1.66 & 9.00 & -37.50 & 8.29 & 4.18 & 4.22 & -244.31 & 5.46 & -0.14 & 11.27 \\
\hline \multicolumn{13}{|c|}{ C. Bear periods-All firms } \\
\hline \multicolumn{13}{|c|}{ C1. Above-median firms } \\
\hline$R O A$ & 3.77 & 55.20 & 8.63 & 4.74 & 4.45 & 35.65 & 9.17 & 4.30 & 3.42 & 55.20 & 8.15 & 5.06 \\
\hline ROE & 10.94 & 423.78 & 20.28 & 16.65 & 12.08 & 423.78 & 22.03 & 20.36 & 9.91 & 190.46 & 18.76 & 12.76 \\
\hline$C R$ & 6.75 & 4789.40 & 16.87 & 131.14 & 8.24 & 67.77 & 14.36 & 6.25 & 5.16 & 4789.40 & 18.63 & 176.68 \\
\hline \multicolumn{13}{|c|}{ C2. Below-median firms } \\
\hline$R O A$ & -39.19 & 3.77 & 0.87 & 3.25 & -39.19 & 4.42 & 1.20 & 3.71 & -26.49 & 3.42 & 0.65 & 2.84 \\
\hline ROE & -1317.82 & 10.93 & 1.53 & 38.74 & -93.03 & 12.08 & 4.80 & 8.36 & -1317.82 & 9.87 & -1.04 & 51.58 \\
\hline$C R$ & -74.67 & 6.75 & 1.77 & 4.96 & -22.46 & 8.21 & 4.16 & 3.48 & -74.67 & 5.15 & 0.12 & 5.51 \\
\hline \multicolumn{13}{|c|}{ D. Overall period-Manufacturing firms } \\
\hline \multicolumn{13}{|c|}{ D1. Above-median firms } \\
\hline$R O A$ & 4.17 & 51.90 & 8.92 & 4.72 & 4.85 & 28.82 & 9.16 & 3.86 & 3.77 & 51.90 & 8.71 & 5.26 \\
\hline$R O E$ & 10.60 & 158.34 & 19.74 & 11.67 & 11.70 & 109.87 & 20.74 & 10.96 & 9.72 & 158.34 & 18.98 & 12.15 \\
\hline$C R$ & 7.14 & 2486.09 & 16.32 & 87.17 & 8.91 & 65.88 & 13.92 & 5.45 & 5.73 & 2486.09 & 17.61 & 113.13 \\
\hline \multicolumn{13}{|c|}{ D2. Below-median firms } \\
\hline$R O A$ & -125.58 & 4.17 & 1.09 & 5.56 & -31.00 & 4.85 & 1.51 & 4.64 & -125.58 & 3.76 & 0.84 & 6.13 \\
\hline ROE & -547.27 & 10.60 & 1.88 & 21.32 & -81.83 & 11.69 & 4.34 & 8.94 & -547.27 & 9.72 & 0.27 & 26.59 \\
\hline$C R$ & -23.96 & 7.13 & 2.70 & 3.76 & -23.96 & 8.90 & 5.30 & 3.81 & -16.07 & 5.69 & 1.26 & 3.22 \\
\hline \multicolumn{13}{|c|}{ E. Overall period-Service firms } \\
\hline \multicolumn{13}{|c|}{ E1. Above-median firms } \\
\hline$R O A$ & 3.33 & 28.33 & 7.90 & 4.28 & 3.87 & 28.33 & 8.73 & 4.63 & 2.93 & 22.68 & 6.94 & 3.70 \\
\hline ROE & 11.87 & 328.58 & 20.80 & 17.70 & 12.40 & 328.58 & 23.34 & 23.04 & 11.10 & 91.73 & 17.95 & 7.86 \\
\hline$C R$ & 5.83 & 125.84 & 13.24 & 8.86 & 7.38 & 47.34 & 14.44 & 6.63 & 4.28 & 125.84 & 11.67 & 10.80 \\
\hline \multicolumn{13}{|c|}{ E2. Below-median firms } \\
\hline$R O A$ & -13.10 & 3.33 & 1.17 & 1.82 & -5.41 & 3.86 & 1.64 & 1.23 & -13.10 & 2.91 & 0.71 & 2.25 \\
\hline ROE & -46.21 & 11.84 & 5.48 & 6.75 & -8.81 & 12.35 & 7.59 & 3.82 & -46.21 & 11.05 & 3.23 & 8.40 \\
\hline$C R$ & -187.76 & 5.82 & 0.59 & 10.47 & -5.26 & 7.36 & 3.15 & 2.43 & -187.76 & 4.25 & -1.95 & 14.58 \\
\hline
\end{tabular}


Table A2. Descriptive statistic results. This table provides mean, maximum, minimum and standard deviation $(S D)$ statistics for partition-firms (overall) for the overall period and also for developed and emerging markets (in \%).

\begin{tabular}{|c|c|c|c|c|c|c|c|c|}
\hline \multicolumn{9}{|c|}{ 1A. Size partitions } \\
\hline \multirow{2}{*}{ Variables } & \multicolumn{4}{|c|}{ Small } & \multicolumn{4}{|c|}{ Large } \\
\hline & Min. & Max. & Mn. & $S D$ & Min. & Max. & Mn. & $S D$ \\
\hline$R O A$ & -125.58 & 51.90 & 4.83 & 6.83 & -13.10 & 41.57 & 4.84 & 4.77 \\
\hline$R O E$ & -127.36 & 328.58 & 10.79 & 17.05 & -547.27 & 109.87 & 12.57 & 18.95 \\
\hline$C R$ & -23.96 & 2486.09 & 10.03 & 69.77 & -187.76 & 65.88 & 7.07 & 9.44 \\
\hline \multicolumn{9}{|c|}{ 1B. Age partitions } \\
\hline & \multicolumn{4}{|c|}{ Young } & \multicolumn{4}{|c|}{ Old } \\
\hline$R O A$ & -125.58 & 28.33 & 4.13 & 6.33 & -16.41 & 51.90 & 5.53 & 5.32 \\
\hline ROE & -547.27 & 328.58 & 9.73 & 21.92 & -127.36 & 158.34 & 13.63 & 12.78 \\
\hline$C R$ & -187.76 & 509.94 & 6.82 & 17.10 & -45.02 & 2486.09 & 10.28 & 68.29 \\
\hline \multicolumn{9}{|c|}{ 1C. Leverage partitions } \\
\hline & \multicolumn{4}{|c|}{ Low leverage } & \multicolumn{4}{|c|}{ High leverage } \\
\hline$R O A$ & -125.58 & 41.57 & 5.86 & 7.19 & -13.03 & 51.90 & 3.81 & 3.95 \\
\hline$R O E$ & -127.36 & 128.68 & 12.92 & 12.83 & -547.27 & 328.58 & 10.44 & 21.99 \\
\hline$C R$ & -187.76 & 125.84 & 8.65 & 10.40 & -80.18 & 2486.09 & 8.46 & 69.67 \\
\hline \multicolumn{9}{|c|}{ 1D. Liquidity partitions } \\
\hline & \multicolumn{4}{|c|}{ Low liquidity } & \multicolumn{4}{|c|}{ High liquidity } \\
\hline$R O A$ & -125.58 & 51.90 & 4.77 & 6.78 & -13.10 & 41.57 & 4.90 & 4.84 \\
\hline$R O E$ & -127.36 & 328.58 & 10.93 & 17.35 & -547.27 & 109.87 & 12.42 & 18.68 \\
\hline$C R$ & -23.96 & 2486.09 & 9.99 & 69.68 & -187.76 & 125.84 & 7.12 & 10.10 \\
\hline \multicolumn{9}{|c|}{ 2A. Size partitions (developed) } \\
\hline \multirow{2}{*}{ Variables } & \multicolumn{4}{|c|}{ Small } & \multicolumn{4}{|c|}{ Large } \\
\hline & Min. & Max. & Mn. & $S D$ & Min. & Max. & Mn. & $S D$ \\
\hline$R O A$ & -31.00 & 28.82 & 6.41 & 6.42 & -4.56 & 23.58 & 4.13 & 3.80 \\
\hline ROE & -81.83 & 328.58 & 15.20 & 19.39 & -13.48 & 109.87 & 12.41 & 10.14 \\
\hline$C R$ & -23.96 & 47.34 & 11.13 & 7.39 & -4.96 & 65.88 & 7.40 & 5.83 \\
\hline \multicolumn{9}{|c|}{ 2B. Age partitions (developed) } \\
\hline & \multicolumn{4}{|c|}{ Young } & \multicolumn{4}{|c|}{ Old } \\
\hline$R O A$ & -31.00 & 28.33 & 5.67 & 6.30 & -11.40 & 28.82 & 4.87 & 4.27 \\
\hline ROE & -81.83 & 328.58 & 14.73 & 19.47 & -28.09 & 101.63 & 12.87 & 10.09 \\
\hline$C R$ & -23.96 & 42.16 & 10.20 & 7.51 & -5.26 & 65.88 & 8.33 & 6.11 \\
\hline \multicolumn{9}{|c|}{ 2C. Leverage partitions (developed) } \\
\hline & \multicolumn{4}{|c|}{ Low leverage } & \multicolumn{4}{|c|}{ High leverage } \\
\hline$R O A$ & -31.00 & 28.82 & 6.15 & 6.35 & -30.07 & 24.28 & 4.40 & 4.04 \\
\hline ROE & -38.16 & 109.87 & 13.84 & 11.55 & -81.83 & 328.58 & 13.77 & 18.68 \\
\hline$C R$ & -23.96 & 65.88 & 10.21 & 7.97 & -17.17 & 37.10 & 8.32 & 5.49 \\
\hline \multicolumn{9}{|c|}{ 2D. Liquidity partitions (developed) } \\
\hline & & Low 1 & idity & & & High 1 & uidity & \\
\hline$R O A$ & -31.00 & 28.82 & 6.08 & 6.29 & -4.56 & 23.58 & 4.46 & 4.16 \\
\hline ROE & -81.83 & 328.58 & 14.87 & 19.20 & -13.48 & 109.87 & 12.73 & 10.57 \\
\hline$C R$ & -23.96 & 47.34 & 10.76 & 7.24 & -4.96 & 65.88 & 7.77 & 6.21 \\
\hline
\end{tabular}


Table A2. Cont.

\begin{tabular}{|c|c|c|c|c|c|c|c|c|}
\hline \multirow{2}{*}{ Variables } & \multicolumn{4}{|c|}{ Small } & \multicolumn{4}{|c|}{ Large } \\
\hline & Min. & Max. & Mn. & $S D$ & Min. & Max. & Mn. & $S D$ \\
\hline \multicolumn{9}{|c|}{ 3A. Size partitions (emerging) } \\
\hline & \multicolumn{4}{|c|}{ Small } & \multicolumn{4}{|c|}{ Large } \\
\hline$R O A$ & -125.58 & 51.90 & 3.47 & 6.82 & -13.10 & 41.57 & 5.48 & 5.43 \\
\hline$R O E$ & -127.36 & 158.34 & 7.19 & 13.81 & -547.27 & 96.95 & 12.69 & 23.88 \\
\hline$C R$ & -16.07 & 2486.09 & 9.23 & 93.87 & -187.76 & 52.02 & 6.72 & 11.60 \\
\hline \multicolumn{9}{|c|}{ 3B. Age partitions (emerging) } \\
\hline & \multicolumn{4}{|c|}{ Young } & \multicolumn{4}{|c|}{ Old } \\
\hline$R O A$ & -125.58 & 26.97 & 3.33 & 6.43 & -13.10 & 51.90 & 5.62 & 5.83 \\
\hline ROE & -547.27 & 128.68 & 6.92 & 23.53 & -127.36 & 158.34 & 12.96 & 14.31 \\
\hline$C R$ & -16.07 & 125.84 & 5.09 & 8.01 & -187.76 & 2486.09 & 10.86 & 94.11 \\
\hline \multicolumn{9}{|c|}{ 3C. Leverage partitions (emerging) } \\
\hline & \multicolumn{4}{|c|}{ Low leverage } & \multicolumn{4}{|c|}{ High leverage } \\
\hline$R O A$ & -125.58 & 41.57 & 5.49 & 7.62 & -13.03 & 51.90 & 3.46 & 4.24 \\
\hline$R O E$ & -127.36 & 128.68 & 11.91 & 13.08 & -547.27 & 158.34 & 7.98 & 24.44 \\
\hline$C R$ & -187.76 & 509.94 & 7.81 & 22.01 & -80.18 & 2486.09 & 8.13 & 91.94 \\
\hline \multicolumn{9}{|c|}{ 3D. Liquidity partitions (emerging) } \\
\hline & \multicolumn{4}{|c|}{ Low liquidity } & \multicolumn{4}{|c|}{ High liquidity } \\
\hline$R O A$ & -125.58 & 51.90 & 3.72 & 6.98 & -13.10 & 41.57 & 5.23 & 5.31 \\
\hline ROE & -127.36 & 158.34 & 7.83 & 14.90 & -547.27 & 96.95 & 12.05 & 23.35 \\
\hline$C R$ & -21.71 & 2486.09 & 9.50 & 93.76 & -187.76 & 125.84 & 6.44 & 12.40 \\
\hline
\end{tabular}

\section{Appendix B}

Calculation of industry-adjusted target return level:

The target return level for firm $f$ in industry $i$ in year $t$, i.e., $I T R_{f, i, t}$, is calculated as the cross-sectional industry mean return for preceding 1 year (henceforth $I T R_{f, i}, 1$ year (simply $I T R_{1}$ year)), and also cross-sectional industry mean return for the preceding 5 years (henceforth $I T R_{f, i}, 5$ years (simply $I T R_{5}$ years $)$ ) on a rolling basis, i.e.,

$$
\begin{gathered}
I T R_{1 \text { year }}=\text { Mean-return } \\
i, t-1 \\
\operatorname{ITR}_{5 \text { years }}=\text { Mean-return } \\
i, t-1, \ldots, t-5
\end{gathered}
$$

Calculation of DT for ITR:

In case of calculating ITR (1 year and 5 years), the above formulae are reproduced in the following ways:

$$
\begin{gathered}
D T R O A_{f, i, t}=A R R O A_{f, i, t}-\text { MeanROA } A_{i, t-1}(1 \text { year }) \\
D T R O A_{f, i, t}=A R R O A_{f, i, t}-\text { MeanROA } A_{i, t-1 \ldots t-5}(5 \text { years }) \\
D T C R_{f, i, t}=A R C R_{f, i, t}-\text { MeanCR }_{i, t-1}(1 \text { year }) \\
\operatorname{DTCR}_{f, i, t}=A R C R_{f, i, t}-\text { MeanCR } R_{i, t-1 . . t-5}(5 \text { years })
\end{gathered}
$$

where:

$\operatorname{DTROA}_{f, i, t}$ and $D T C R_{f, i, t}=$ Distance from the target return level of the cross-sectional industry mean return (i.e., $I T R_{f, i, t}$ ) in year $t$. 
$A R R O A_{f, i, t}$ and $A R C R_{f, i, t}=$ Actual return of $R O A$ and $C R$ respectively, for firm $f$ in industry $i$ in year $t$.

MeanROA $A_{i, t-1}$ and MeanCR $R_{i, t-1}=$ Cross-sectional industry mean return of $R O A$ and $C R$ respectively, for industry $i$ in year $t-1$ (i.e., preceding year) on a rolling basis.

MeanROA $A_{i, t-1 \ldots t-5}$ and MeanCR $R_{i, t-1 \ldots t-5}=$ Cross-sectional industry mean return of $R O A$ and $C R$ respectively, for industry $i$ in year $t-1 \ldots t-5$ (i.e., preceding 5 years) on a rolling basis.

Use of Kendall's tau over and above Pearson and Spearman:

There are standard guidelines on when to use Pearson's (1895), Spearman's (1904) or Kendall's (1938) correlation coefficients. The guideline decision based on the type of the data being analyzed (see e.g., Abdullah 1990; Balakrishna and Lai 2009; etc.) indicates that the Pearson's product moment correlation coefficient is appropriate only for interval data while the Spearman's and Kendall's correlation coefficients can be used for either ordinal or interval data. Also, the Pearson product moment correlation is a natural parameter of association for a bi-variate normal distribution (i.e., it assumes zero value if and only if the two variables are independent). However, for non-normal data, the sensitivity of the Pearson product moment correlation coefficient has led to criticisms and recommends uses of other correlation coefficients. This is due to the fact that by replacing the observations by their ranks, the effect of the outliers may be reduced (Abdullah 1990; and Balakrishna and Lai 2009).

Kendall's $\tau$ is even less sensitive to outliers and is often preferred due to its simplicity and ease of interpretation (Kendall 1938). Also, this non-parametric procedure is helpful in comparing the ability of the correlation coefficients to reflect a given monotone association, aside from the possible differences caused by discrepancies in the statistical testing procedures.

Multivariate regression equation variables descriptions:

$S I Z E_{f, t}=$ Size of the firm measured by book value of assets (average) of firm $f$ in year $t$.

$A G E_{f, t}=$ Age of firm at the point of analysis.

$L E V E R A G E_{f, t}=$ Risk measured by debt-equity ratio of firm $f$ in year $t$.

$\operatorname{LIQUIDITY}_{f, t}=$ Liquidity (i.e., cash holdings) of the firm measured by cash and cash equivalents (average) of firm $f$ in year $t$.

RELATEDDIVERSIFICATION f $_{, t}=$ Related diversified firm $(=1)$ and others $(=0)($ dummy 1$)$

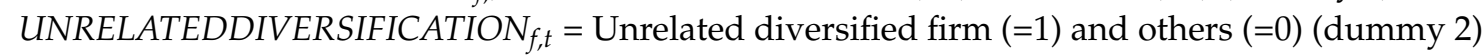
FINANCIALFIRM $_{f, t}=$ Financial firm $(=1)$ and others $(=0)$ (dummy 3$)$.

\section{References}

Aaker, David A., and Robert Jacobson. 1987. The role of risk in explaining differences in profitability. Academy of Management Journal 30: 277-96.

Abdullah, Mokhtar Bin. 1990. On a robust correlation coefficient. The Statistician 39: 455-60. [CrossRef]

Acharya, Viral V., Heitor Almeida, and Murillo Campello. 2007. Is Cash Negative Debt? A Hedging Perspective on Corporate Financial Policies. Journal of Financial Intermediation 16: 515-54. [CrossRef]

Albrecht, W. Steve, Conan C. Albrecht, and Chad O. Albrecht. 2004. Fraud and corporate executives: Agency, stewardship and broken trust. Journal of Forensic Accounting 5: 109-30.

Arellano, Manuel, and Olympia Bover. 1995. Another look at the instrumental variable estimation of error-components models. Journal of Econometrics 68: 29-51. [CrossRef]

Armour, Henry Ogden, and David J. Teece. 1978. Organizational structure and economic performance: A test of the multidivisional hypothesis. The Bell Journal of Economics 9: 106-22. [CrossRef]

Bae, Sung C., Kiyoung Chang, and Eun Kang. 2012. Culture, corporate governance, and dividend policy: International evidence. Journal of Financial Research 35: 289-316. [CrossRef]

Balakrishna, N., and Chin Diew Lai. 2009. Bivariate distributions constructed by the conditional Approach. In Continuous Bivariate Distributions. New York: Springer, pp. 229-78. 
Baskin, Jonathan. 1987. Corporate liquidity in games of monopoly power. The Review of Economics and Statistics 69: 312-19. [CrossRef]

Baucus, David A., Joseph H. Golec, and Juett R. Cooper. 1993. Estimating risk-return relationships: An analysis of measures. Strategic Management Journal 14: 387-96. [CrossRef]

Becerra, Manuel, and Garren Markarian. 2013. The Bowman Paradox and Industry Competition: Dynamics of the Risk-Performance Relationship. Paper presented at XXXVIII Jornadas de Economia Industrial, Madrid, Spain, May 23; pp. 1-40.

Bettis, Richard A. 1981. Performance differences in related and unrelated diversified firms. Strategic Management Journal 2: 379-93. [CrossRef]

Bettis, Richard A., and Vijay Mahajan. 1985. Risk/return performance of diversified firms. Management Science 31: 785-99. [CrossRef]

Bettis, Richard A., and William K. Hall. 1982. Diversification strategy, accounting determined risk and accounting determined return. Academy of Management Journal 25: 254-64.

Bigus, Jochen. 2015. Loss aversion, audit risk judgments, and auditor liability. European Accounting Review 24: 581-606. [CrossRef]

Black, Fisher. 1976. Studies of Stock Price Volatility Changes. Washington, DC: American Statistical Association, pp. 177-81.

Blundell, Richard, and Stephen Bond. 1998. Initial conditions and moment restrictions in dynamic panel data models. Journal of Econometrics 87: 115-43. [CrossRef]

Bowman, Edward H. 1980. A risk/return paradox for strategic management. Sloan Management Review 21: 17-31.

Bowman, Edward H. 1982. Risk seeking by troubled firms. Sloan Management Review 23: 33-42.

Bowman, Edward H. 1984. Content analysis of annual reports for corporate strategy and risk. Interfaces 14: 61-71. [CrossRef]

Brealey, Richard A., Stewart C. Myers, and Franklin Allen. 2017. Principles of Corporate Finance, 12nd ed. New York: McGraw-Hill.

Brick, Ivan E., Oded Palmon, and Itzhak Venezia. 2015. On the Relationship between Accounting Risk and Return: Is There a (Bowman) Paradox? European Management Review 12: 99-111. [CrossRef]

Bromiley, Philip. 1991. Testing a Causal Model of Corporate Risk Taking and Performance. Academy of Management Journal 34: 37-59.

Bruinshoofd, Allard, and Leo De Haan. 2005. Financing the New Economy: Are ICT Firms Really that Different? Amsterdam: De Nederlandsche Bank.

Buvanendra, Shantharuby, P. Sridharan, and S. Thiyagarajan. 2017. Firm characteristics, corporate governance and capital structure adjustments: A comparative study of listed firms in Sri Lanka and India. IIMB Management Review 29: 245-58. [CrossRef]

Chang, Yegmin, and Howard Thomas. 1989. The impact of diversification strategy on risk-return performance. Strategic Management Journal 10: 271-84. [CrossRef]

Chen, Peter Y., and Paula M. Popovich. 2002. Correlation: Parametric and Nonparametric Measures. Thousand Oaks: Sage Publications Inc.

Chou, Pin -Huang, Robin K. Chou, and Kuan -Cheng Ko. 2009. Prospect theory and the risk-return paradox: Some recent evidence. Review of Quantitative Finance and Accounting 33: 193-208. [CrossRef]

Christie, Andrew A. 1982. The stochastic behavior of common stock variances: Value, leverage and interest rate effects. Journal of Financial Economics 10: 407-32. [CrossRef]

Cool, Karel, Ingemar Dierickx, and David Jemison. 1989. Business strategy, market structure and risk-return relationships: A structural approach. Strategic Management Journal 10: 507-22. [CrossRef]

Cyert, Richard M., and James G. March. 1992. A Behavioral Theory of the Firm. Englewood Cliffs: Prentice-Hall.

Dang, Chongyu, Zhichuan Frank Li, and Chen Yang. 2018. Measuring firm size in empirical corporate finance. Journal of Banking \& Finance 86: 159-76.

DasGupta, Ranjan. 2017. Risk-Attitudes of the NSE 500 Firms-Bowman's Paradox and Prospect Theory Perspectives. IIMB Management Review 29: 76-89. [CrossRef]

Deephouse, David L., and Robert M. Wiseman. 2000. Comparing alternative explanations for accounting risk-return relations. Journal of Economic Behaviorand Organization 42: 463-82. [CrossRef]

Denis, David J. 2011. Financial flexibility and corporate liquidity. Journal of Corporate Finance 17: 667-74. [CrossRef] 
Díez-Estebana, Jose Maria, Conrado Diego García-Gómezb, Felix Javier López-Iturriagac, and Marcos Santamaría-Mariscal. 2017. Corporate risk-taking, returns and the nature of major shareholders: Evidence from prospect theory. Research in International Business and Finance 42: 900-11. [CrossRef]

Ferreira, Miguel A., and Antonio S. Vilela. 2004. Why do firms hold cash? Evidence from EMU countries. European Financial Management 10: 295-319. [CrossRef]

Fiegenbaum, Avi. 1990. Prospect Theory and the Risk-Return Association: An Empirical Examination of 85 Industries. Journal of Economic Behavior and Organization 14: 187-203. [CrossRef]

Fiegenbaum, Avi, and Howard Thomas. 1988. Attitudes toward risk and the risk-return paradox prospect theory explanations. Academy of Management Journal 73: 337-63.

Fiegenbaum, Avi, and Howard Thomas. 2004. Strategic risk and competitive advantage: An integrative perspective. European Management Review 1: 84-95. [CrossRef]

Fishburn, Peter C. 1977. Mean-Risk Analysis with Risk Associated with Below-Target Returns. American Economic Review 67: 116-26.

Fisher, Irving N., and George R. Hall. 1969. Risk and corporate rates of return. The Quarterly Journal of Economics 83: 79-92. [CrossRef]

Frecka, Thomas J., and Cheng F. Lee. 1983. Generalized Financial Ratio Adjustment Processes and Their Implications. Journal of Accounting Research 21: 308-16. [CrossRef]

Gaud, Philippe, Elion Jani, Martin E. R. Hoesli, and Andre Bender. 2005. The capital structure of Swiss companies: An empirical analysis using dynamic panel data. European Financial Management 11: 51-69. [CrossRef]

Greene, William H. 2008. The econometric approach to efficiency analysis. The Measurement of Productive Efficiency and Productivity Growth 1: 92-250.

Harford, Jarrad, Wayne Mikkelson, and M. Megan Partch. 2003. The Effect of Cash Reserves on Corporate Investment and Performance in Industry Downturns. Unpublished working paper.

Haushalter, David, Sandy Klasa, and William F. Maxwell. 2007. The influence of product market dynamics on a firm's cash holdings and hedging behavior. Journal of Financial Economics 84: 797-825. [CrossRef]

Heggestad, Arnold A. 1977. Market structure, risk and profitability in commercial banking. The Journal of Finance 32: 1207-16. [CrossRef]

Henkel, Joachim. 2000. The risk-return fallacy. Schmalenbach Business Review: ZFBF 52: 363. [CrossRef]

Hofstede, Geert. 2001. Culture Consequences: Comparing Values, Behaviors, Institutions and Organizations across Nations. London: SAGE.

Holder, Anthony Dewayne, Alexey Petkevich, and Gary Moore. 2016. Does managerial myopia explain Bowman's Paradox? American Journal of Business 31: 102-22. [CrossRef]

Horowitz, Joel L., Tim Loughran, and Nathan E. Savin. 2000. Three analyses of the firm size premium. Journal of Empirical Finance 7: 143-53. [CrossRef]

Jemison, David B. 1987. Risk and the relationship among strategy, organizational processes, and performance. Management Science 33: 1087-101. [CrossRef]

John, Teresa A. 1993. Accounting measures of corporate liquidity, leverage, and costs of financial distress. Financial Management 22: 91-100. [CrossRef]

Kahneman, Daniel, and Amos Tversky. 1979. Prospect theory: An analysis of decision under risk. Econometrica 47: 263-91. [CrossRef]

Kendall, Maurice. 1938. A New Measure of Rank Correlation. Biometrika 30: 81-89. [CrossRef]

Kliger, Doron, and Iris Tsur. 2011. Prospect Theory and Risk-Seeking Behavior by Troubled Firms. Journal of Behavioral Finance 12: 29-40. [CrossRef]

Knez, Peter J., and Mark J. Ready. 1997. On the robustness of size and book-to-market in cross-sectional regressions. The Journal of Finance 52: 1355-82. [CrossRef]

Lee, Don Y. 1997. The Impact of Poor Performance on Risk-Taking Attitudes: A Longitudinal Study with a PLS Causal Modeling Approach. Decision Sciences 28: 59-80. [CrossRef]

Lehner, Johannes M. 2000. Shifts of Reference Points for Framing of Strategic Decisions and Changing Risk-Return Associations. Management Science 46: 63-76. [CrossRef]

Lev, Baruch. 1969. Industry Averages as Targets for Financial Ratios. Journal of Accounting Research 7: $290-99$. [CrossRef]

Li, Kai, Dale Griffin, Heng Yue, and Longkai Zhao. 2013. How does culture influence corporate risk-taking? Journal of Corporate Finance 23: 1-22. [CrossRef] 
Liebetrau, Albert M. 1976. Measures of Association. Beverly Hills and London: Sage Publications Inc.

Miller, Kent D., and Michael J. Leiblein. 1996. Corporate risk-return relations: Returns variability versus downside risk. The Academy of Management Journal 39: 91-122.

Miller, Kent D., and Philip Bromiley. 1991. Strategic risk and corporate performance: An analysis of alternative risk measures. Academy of Management Journal 33: 756-79.

Miller, Kent D., and Wei-Ru Chen. 2003. Risk and firms' costs. Strategic Organization 1: 355-82. [CrossRef]

Myers, Stewart C. 1984. The capital structure puzzle. The Journal of Finance 39: 574-92. [CrossRef]

Nenu, Elena Alexandra, Georgeta Vintilă, and Stefan Cristian Gherghina. 2018. The Impact of Capital Structure on Risk and Firm Performance: Empirical Evidence for the Bucharest Stock Exchange Listed Companies. International Journal of Financial Studies 6: 41. [CrossRef]

Opler, Tim, Lee Pinkowitz, Rene Stulz, and Rohan Williamson. 1999. The determinants and implications of corporate cash holdings. Journal of Financial Economics 52: 3-46. [CrossRef]

Oviatt, Benjamin M., and Alan D. Bauerschmidt. 1991. Business Risk and Return: A Test of Simultaneous Relationships. Management Science 37: 1405-23. [CrossRef]

Ozkan, Aydin, and Neslihan Ozkan. 2004. Corporate cash holdings: An empirical investigation of UK companies. Journal of Banking E Finance 28: 2103-34.

Pearson, Karl. 1895. Contributions to the mathematical theory of evolution. II. Skew variation in homogeneous material. Philosophical Transactions of the Royal Society of London 186: 343-424. [CrossRef]

Perlitz, Manfred, and Helge Löbler. 1985. Brauchen Unternehmenzum Innovieren Krisen. Zeitschrift für Betriebswirtschaft 55: 424-50.

Petrou, Andreas P., and Andreas Procopiou. 2016. CEO shareholdings and earnings manipulation: A behavioral explanation. European Management Review 13: 137-48. [CrossRef]

Ramirez, Andres, and Solomon Tadesse. 2009. Corporate cash holdings, uncertainty avoidance, and the multinationality of firms. International Business Review 18: 387-403. [CrossRef]

Roodman, David. 2009. How to do xtabond2: An introduction to difference and system GMM in Stata. Stata Journal 9: 86-136. [CrossRef]

Ross, Stephen A. 1973. The economic theory of agency: The principal's problem. American Economic Review 63: 134-39.

Ruefli, Timothy W., James M. Collins, and Joseph R. Lacugna. 1999. Risk measures in strategic management research: Auld Lang Syne. Strategic Management Journal 20: 167-94. [CrossRef]

Schoemaker, Paul J. H. 1982. The expected utility model: Its variants, purpose, evidence, and limitations. Journal of Economic Literature 20: 529-63.

Spearman, Charles. 1904. The proof and measurement of association between two things. The American Journal of Psychology 15: 72-101. [CrossRef]

Subramaniam, Venkat, Tony T. Tang, Heng Yue, and Xin Zhou. 2011. Firm structure and corporate cash holdings. Journal of Corporate Finance 17: 759-73. [CrossRef]

Tversky, Amos, and Daniel Kahneman. 1992. Advances in prospect theory: Cumulative representation of uncertainty. Journal of Risk and Uncertainty 5: 297-323. [CrossRef]

Von Neumann, John, and Oskar Morgenstern. 1944. Theory of Games and Economic Behavior. Princeton: Princeton University Press.

Wafa, Khemiri, and Noubbigh Hédi. 2018. Determinants of capital structure: Evidence from sub-Saharan African firms. The Quarterly Review of Economics and Finance. [CrossRef]

Wiemann, Volker, and Thomas Mellewigt. 1998. Das Risiko-Rendite Paradoxon. Stand der Forschung und Ergebnisse einer empirischen Untersuchung. Schmalenbachs Zeitschrift für Betriebswirtschaftliche Forschung 50: 551-72. [CrossRef]

Wiseman, Robert, and Philip Bromiley. 1991. Risk-Return Associations: Paradox or Artifact? An Empirical Tested Explanation. Strategic Management Journal 12: 231-41. [CrossRef]

Woo, Carolyn Y. 1987. Path analysis of the relationship between market share, business-level conduct and risk. Strategic Management Journal 8: 149-68. [CrossRef]

(C) 2018 by the authors. Licensee MDPI, Basel, Switzerland. This article is an open access article distributed under the terms and conditions of the Creative Commons Attribution (CC BY) license (http:/ / creativecommons.org/licenses/by/4.0/). 